\title{
SEISMIC HAZARD IN GREECE. I. MAGNITUDE RECURRENCE
}

\author{
KOSTAS C. MAKROPOULOS ${ }^{1}$ and PAUL W. BURTON ${ }^{2}$ \\ I Seismological laboratory, University of Athens, Panepistimiopoli, Athens 157-84 (Greece) \\ 2 Natural Environment Research Council, British Geological Survey, Murchison House, West Mains Road, \\ Edinburgh EH9 3 LA (Great Britain)
}

(Received February 23, 1984; revised versicn accepted October 26, 1984)

\begin{abstract}
Makropoulos, K.C. and Burton, P.W., 1985. Seismic hazard in Greece. I. Magnitude recurrence. Tectonophysics, 117: 205-257.
\end{abstract}

Two different methods are applied to the earthquake catalogue for Greece (Makropoulos and Burton, 1981), MB catalogue, to evaluate Greek seismic hazard in terms of magnitude: earthquake strain energy release and Gumbel's third asymptotic distribution of extreme values.

It is found that there is a close relationship between results from the two methods. In places where the cumulative strain energy release graphs include at least one well defined cycle of periodicity of strain release, then the parameters of the third type asymptote are well defined with small uncertainties. In almost all cases the magnitude distribution shows a remarkably good third type asymptotic behaviour.

The results are presented in the form of graphs and contour maps of annual and 80-year modes, and magnitudes with $70 \%$ probability of not being exceeded in the next 50 and 100 years. For six of the most heavily industrial and highly populated centres of Greece magnitude hazard parameters are also derived and examined in more detail, thereby illustrating the direct applicability of the methods in terms of zoning. The close agreement between observed and predicted extreme magnitudes shows that the sample period considered (1900 1978), is long enough to obtain statistically stable estimates.

For Athens the upper bound magnitude is found to be $6.7 \pm 0.3$ (within $100 \mathrm{~km}$ ) and $6.8 \pm 0.4(100 \mathrm{~km})$ from the two methods respectively, whereas for Corinth an earthquake of magnitude 6.5 has a mean return period of 43 years. Greece as a whole has an upper bound magnitude $8.7 \pm 0.6$ and earthquakes of a size similar to the 1903 Kithira event $(M \approx 8.0)$ have a mean return period of about 200 years.

The significantly different maps contouring magnitudes of the annual and 80 -year modes result from the fact that each place has its own distribution curvature for magnitude occurrence, and thus they are not a linear extrapolation of each other. However, as longer return periods are considered, these differences become small because the expected magnitudes approach the regional upper bound.

A feature common to all these maps is the existence of three well defined aseismic blocks: (a) the Attikocycladic block, (b) the Ptolemais basin and (c) the block formed by the northeastern part of Greece. Well defined areas of high seismic hazard which correlate with the most tectonically active areas are: (a) along the Hellenic arc: the Greek-Albania border, Leukas-Cephalonia Islands and the southeastern end of the arc; (b) the western end of the North Anatolian fault and (c) the Chalkidiki peninsula and the northern Sporadhes Islands. 


\section{INTRODUCTION}

Several attempts have been made to map seismicity and seismic hazard of Greece Galanopoulos (1968) calculated the seismic hazard expressed as the recurrence rates of shallow earthquakes with $m>5 \frac{1}{2}, 6,6 \frac{1}{2}$, and 7 in each square degree of Greece. Comninakis (1975) defined the seismic hazard in terms of the most probable annual maximum magnitude from the Gutenberg-Richter cumulative frequency-magnitude $a$ and $b$ values per square degree and for the sample period 1911 to 1970. Algermissen et al. (1976) used the Shebalin et al. (1974) catalogue to compile seismic hazard maps of the Balkan region, depicting acceleration and velocity with $70 \%$ probability of not being exceeded in 25 and 200 year periods. More recently Bath (1983) examined earthquake frequency and energy in Greece using the Makropoulo. and Burton (1981), MB catalogue, which will also be the subject of hazard analysis here.

The calculation of seismic hazard in terms of expected magnitude, acceleration. velocity or displacement, may depend on the time span considered (even if timt* invariance is assumed in the long term) and also on the earthquake parameters used. If the time span is not sufficient to establish stable estimates of hazard, then ensuing hazard maps may differ for different periods of observation. Thus, comparison between the two maps of Galanopoulos (1968) and Comninakis (1975) shows different results for the area of the north Aegean, because the first map was compiled before strong activity in the north Aegean during 1965-1967. On the other hand, any uncertainty or significant revision in magnitude produces a related uncertainty in, or requires a re-calculation of, the seismic hazard parameters.

The Makropoulos and Burton (1981) catalogue for Greece will be used here to evaluate Greek seismic hazard in terms of magnitude using two different methods: earthquake strain energy release, and Gumbel's third asymptotic distribution of extreme values; both established methodologies are outlined briefly below. The results are presented mainly in the form of contour maps of annual and 80-year most probable maximum magnitudes (modes), and magnitudes with $70 \%$ probability of not being exceeded in the next 50 and 100 years. Seismic hazard for six of the most heavily industrial and highly populated centres of Greece is exanined in more detail illustrating the direct applicability of the methods as well as general utility of the contoured maps in terms of zoning. A second briefer paper will obtain hazard calculations in terms of ground acceleration throughout Greece.

EARTHQUAKE DATA

Several earthquake catalogues have been published for Greece and the surrounding area, the more pertinent of which include Galanopoulos (1960, 1961, 1963), Shebalin et al. (1974) UNS catalogue, Comninakis and Papazachos $(1978,1982)$ and Makropoulos and Burton (1981) MB catalogue. 
Prior to 1917 the MB catalogue relies heavily on UNS, and from 1964 onwards on hypocentre determinations of the International Seismological Centre, ISC. For the period 1917-1963 most earthquakes have all parameters calculated using the Joint Epicentre Determination method (Douglas, Young and Lilwall, 1974; Douglas, 1976), and magnitudes during the period 1908-1977 are determined using the Swedish network ground amplitude records in a manner similar to Alsan et al. (1975). The magnitudes are rendered equivalent to the surface wave magnitude $M_{\mathrm{s}}$ scale. The catalogue has thus been made as homogeneous as possible. Makropoulos and Burton (1981) give a full description of the method of production and the contents of this catalogue, including its magnitude completeness. The epicentral distribution of the catalogued earthquakes is shown in their fig. 9 (Makropoulos and Burton, 1981), and Makropoulos and Burton (1984) discuss scismotectonic implications of the overall three-dimensional hypocentral distribution.

\section{METHODOLOGIES OF GUMBEL III AND STRAIN ENERGY RELEASE}

Two methodologies will be applied here to indicate seismic hazard. First, the "part process" asymptotic distribution of extreme values (Gumbel, 1966) will be used to obtain estimates of magnitude recurrence with associated uncertainties and return periods. Secondly, the "whole process" will be used to analyse physical strain energy release in time, and to estimate both the mean annual strain energy release and a largest earthquake magnitude compatible with the maximum conceivable strain energy release in a region.

Extreme value distributions have the advantages that detailed knowledge of the parent distribution is not required, and the extreme values themselves are usually better known than the smaller events in a catalogue or time series of data. Use of extreme values will also eliminate most significant aftershocks from the analysis and maintain emphasis on what are held to be independent events. The extreme value distribution with an upper bound is used here (also see, for example, Yegulalp and Kuo, 1966, 1974), called Gumbel III, and of form:

$P(m)=\exp \left[-\left(\frac{\omega-m}{\omega-u}\right)^{k}\right]$

with three parameters: an upper bound magnitude $\omega$, a characteristic extreme magnitude value $u$, and $k(=1 / \lambda)$ relating to distribution curvature. $P$ is the probability that a magnitude $m$ is an annual extreme. The principles by which we fit (1) to the observed data are described in detail elsewhere (e.g., Burton, 1979) and we shall not elaborate here. A principal advantage of the method is that it allows full evaluation of the error or covariance matrix $\epsilon$ amongst parameters $(\omega, u, \lambda)$ :

$\epsilon=\left[\begin{array}{ccc}\sigma_{\omega}^{2} & \sigma_{u \omega}^{2} & \sigma_{\lambda \omega}^{2} \\ \sigma_{\omega u}^{2} & \sigma_{u}^{2} & \sigma_{\lambda u}^{2} \\ \sigma_{\omega \lambda}^{2} & \sigma_{u \lambda}^{2} & \sigma_{\lambda}^{2}\end{array}\right]$ 
where $\sigma_{\omega}^{2}$ is the variance on parameter $\omega$ etc. Knowledge of all $\epsilon_{i j}$ is vital when assessing uncertainties on forecasts. The average return period $T(m)$ years for a magnitude $m$ earthquake is:

$T(m)=1 /(1-P(m))$

and the modal or most probable annual maximum $m(1)$ satisfying $\mathrm{d}^{2} P / \mathrm{d}^{2}=0$ is:

$m(1)=\omega-(\omega-u)(1-\lambda)^{\lambda}$

Gumbel III is skew and the associated probability that the annual mode is an annual extreme is $\exp [-(1-\lambda)]$, which for a typical $\lambda \approx 0.3$ implies $P \approx 0.497$ and an average return period a little under two years. The $T$-year modal maximum satisfying $\mathrm{d}^{2} P^{T} / \mathrm{d} m^{2}=0$ is:

$m(T)=\omega-(\omega-u)[(1-\lambda) / T]^{\lambda}$

Finally, the earthquake magnitude with probability $P$ of being a maximum or not being exceeded in the next $T$ years is:

$m_{P}(T)=\omega-(\omega-u)[(-\ln P) / T]^{\lambda}$

with a corresponding average return period $T^{\prime}$-years:

$T^{\prime}=1 /\left(1-P^{1 / T}\right)$

It is useful to be able to calculate uncertainties $\sigma_{m}$ on forecasts of $m(T)$ etc. It is essential to allow $m(T)+\sigma_{m}$ to exceed $\omega$, because although $\omega$ is an upper bound, in practice it is found with large $\sigma_{\omega}^{2}$ implying large uncertainty in this single parameter of the distribution. A realistic estimate of the prediction uncertainty $\sigma_{m}$ is obtained from the linear combination:

$\sigma_{m}^{2} \approx \sigma_{\omega}^{2}\left(\frac{\partial m}{\partial \omega}\right)^{2}+\sigma_{\lambda}^{2}\left(\frac{\partial m}{\partial \lambda}\right)^{2}+\sigma_{u}^{2}\left(\frac{\partial m}{\partial u}\right)^{2}+2 \sigma_{\omega \lambda}^{2}\left(\frac{\partial m}{\partial \omega}\right)^{2}\left(\frac{\partial m}{\partial \lambda}\right)^{2}+\ldots$

and since $\sigma_{\omega \lambda}^{2}$ is typically large and negative (Burton, 1978) it is important to use all $\epsilon_{i j}$

We also wish to make comparison with both the commonly used Gutenterg-Richter (1944) cumulative frequency-magnitude law $(\log N(m)=a-$ $b m$, where $a$ and $b$ are constants and $N(m)$ is the cumulative exceedance of magnitude $m$ ) and also with the whole process of physical strain energy release. To this end we have defined three magnitudes $M_{1}, M_{2}$ and $M_{3}$ (Makropoulos and Burton, 1983):

$M_{1}$ : the modal or most probable annual maximum magnitude determined from the Gutenberg-Richter relationship. (It is clear that $M_{1}=a / b$, and is directly analogous to $m(1)$ of (4) from Gumbel III.)

$M_{2}$ : the magnitude equivalent to the mean annual rate of strain energy release (with the equivalence between magnitude and energy $E$ coming from Băth's (1958) form of the equation $\log E=A+B m$ ). (For the Gumbel III equivalent see (9) below.) 
$M_{3}$ : the upper bound magnitude equivalent to the maximum strain energy release in a region. ( $M_{3}$ may be compared with $\omega$ ).

Makropoulos and Burton (1983) estimate $M_{2}$ and $M_{3}$ both graphically and analytically, and previous uses of such strain energy diagrams are referenced there. The original use of such diagrams seems to go back to Benioff (1951). The ensuing figures (see Fig. 1a) in this paper illustrate the straightforward nature of graphical estimation of $M_{2}$ and $M_{3} ; M_{2}$ is casily calculated analytically, and $M_{3}$ may be obtained analytically from:

$M_{3}=\left[B M_{2}-a-\log \{b /(B-b)\}\right] /(B-b)$

A "waiting time" required to store strain energy equivalent to the maximum strain energy release earthquake $M_{3}$ is associated with each $M_{3}$. Although $M_{3}$ and $\omega$ may be compared it should be borne in mind that there are fundamental differences of concept. $\omega$ corresponds to an impossible but theoretically infinite average return period, whereas $M_{3}$ corresponds to a finite "waiting time" which is more compatible with intuitive concepts of the strain energy release process.

The Gumbel III parameters $(\omega, u, \lambda)$ may also be related (Burton and Makropoulos, 1983) to a magnitude $X_{2}$ representing the mean annual rate of energy release through

$$
\begin{aligned}
& X_{2}=\omega+\frac{1}{B_{1}} \ln \left[(C \Gamma(k)) / B_{1}^{k}\right] \\
& C=k /(\omega-u)^{k} \\
& B_{1}=B \ln 10
\end{aligned}
$$

To summarise, when the ensuing results are scrutinised (particularly the tables): $m(1)$ and $M_{1}$ compare annual maxima estimated from the part process Gumbel III and the whole process Gutenberg-Richter laws; $X_{2}$ and $M_{2}$ compare the magnitude equivalent to the mean annual strain energy release as estimated from the part process Gumbell III statistics and from the physical process of strain energy release respectively; $\omega$ and $M_{3}$ compare the upper limiting magnitude parameter of Gumbel III with the magnitude equivalent to the maximum strain energy which may be stored and released in a region, despite the latters conceptual difference.

\section{MAGNITUDE SEISMIC HAZARD}

The methods of the previous section are now applied to the MB catalogue to evaluate magnitude seismic hazard for Greece as a whole, and for the six following major cities in Greece:

$\begin{array}{llllll}\text { Athens } & 37.97^{\circ} \mathrm{N} & 23.72^{\circ} \mathrm{E} & \text { Corinth } & 37.92^{\circ} \mathrm{N} & 22.93^{\circ} \mathrm{E} \\ \text { Thessaloniki } & 40.64^{\circ} \mathrm{N} & 22.93^{\circ} \mathrm{E} & \text { Heraklion } & 35.35^{\circ} \mathrm{N} & 25.18^{\circ} \mathrm{E} \\ \text { Patras } & 38.23^{\circ} \mathrm{N} & 21.75^{\circ} \mathrm{E} & \text { Rodhos } & 36.43^{\circ} \mathrm{N} & 28.27^{\circ} \mathrm{E}\end{array}$


For each of these cities the distribution of shallow plus intermediate earthquakes for a radius of $100 \mathrm{~km}$ and $150 \mathrm{~km}$ from their centres, is taken and analysed, with both strain energy release and extreme value methods. These radii are chosen in order to obtain estimates of the seismic risk more applicable to normal and tall structures. Normal size buildings are mainly subject to the seismic hazard associated with strong local earthquakes with high frequency seismic waves ( $\geqslant 3 \mathrm{~Hz}$ ), whereas tall buildings with longer resonant periods can be seriously affected by more distant earthquakes.

Table 1 tabulates the three parameters $(\omega, u, \lambda)$ of the third type asymptotic distribution, along with their uncertainties and the reduced chi-square indicating goodness of fit obtained between the observed annual estimates and the fitted Gumbell III. The parameters $(\omega, u, \lambda)$ are calculated using annual extremes in all cases. The column "missing years" contains the number of years without reported earthquakes.

The results for $M_{1}, M_{2}$ and $M_{3}$ using the method of strain energy release, and the comparable quantities $m(1), X_{2}$ and $\omega$ derived from the parameters of Table 1 using (4) and (9) are listed in Table 2. The Figs. 1-7 illustrate both methods for all Greece and each of the six cities.

TABLE 1

Estimated parameters $(\omega, u, \lambda)$ and uncertainties for the Gumbel III distribution

\begin{tabular}{lllllllll}
\hline Place & $\omega$ & $\sigma_{\omega}$ & $u$ & $\sigma_{u}$ & $\lambda$ & $\sigma_{\lambda}$ & $\begin{array}{l}\text { Reduced } \\
\text { chi-square }\end{array}$ & $\begin{array}{l}\text { Missing } \\
\text { years }\end{array}$ \\
\hline Athens (100) & 6.80 & \pm 0.39 & 2.98 & \pm 0.52 & 0.595 & \pm 0.193 & 0.027 & 47 \\
Athens (150) & 7.35 & \pm 0.58 & 4.19 & \pm 0.21 & 0.402 & \pm 0.151 & 0.042 & 38 \\
Thessaloniki (100) & 8.19 & \pm 1.17 & 2.39 & \pm 0.77 & 0.363 & \pm 0.169 & 0.232 & 58 \\
Thessaloniki (150) & 8.57 & \pm 0.83 & 3.58 & \pm 0.30 & 0.346 & \pm 0.119 & 0.159 & 45 \\
Patras (100) & 6.69 & \pm 0.46 & 4.12 & \pm 0.26 & 0.504 & \pm 0.206 & 0.035 & 40 \\
Patras (150) & 8.23 & \pm 0.99 & 5.12 & \pm 0.07 & 0.238 & \pm 0.111 & 0.039 & 21 \\
Corinth (100) & 6.75 & \pm 0.32 & 3.66 & \pm 0.41 & 0.671 & \pm 0.220 & 0.046 & 43 \\
Corinth (150) & 7.15 & \pm 0.44 & 4.68 & \pm 0.11 & 0.432 & \pm 0.147 & 0.074 & 29 \\
Heraklion (100) & 7.86 & \pm 1.17 & 3.73 & \pm 0.32 & 0.291 & \pm 0.158 & 0.128 & 46 \\
Heraklion (150) & 8.93 & \pm 1.97 & 4.87 & \pm 0.09 & 0.176 & \pm 0.117 & 0.046 & 27 \\
Rodhos (100) & 9.23 & \pm 3.29 & 3.88 & \pm 0.31 & 0.170 & \pm 0.158 & 0.146 & 48 \\
Rodhos (150) & 9.39 & \pm 2.02 & 4.53 & \pm 0.12 & 0.176 & \pm 0.062 & 0.046 & 38 \\
Greece & 8.73 & \pm 0.65 & 6.21 & \pm 0.04 & 0.236 & \pm 0.073 & 0.023 & 0 \\
\hline
\end{tabular}


TABLE 2

Estimated parameters from the strain energy release method *

\begin{tabular}{|c|c|c|c|c|c|c|c|}
\hline Place & $M_{1}$ & $m(1)$ & $M_{2}$ & $X_{2}$ & $M_{3}$ & $\omega$ & $\begin{array}{l}\text { Waiting } \\
\text { time } \\
\text { (years) }\end{array}$ \\
\hline Athens $(100)$ & $\begin{array}{l}4.2 \\
\pm 0.1\end{array}$ & $\begin{array}{l}4.5 \\
\pm 0.1\end{array}$ & $\begin{array}{l}5.7 \\
\pm 0.1\end{array}$ & $\begin{array}{l}5.9 \\
\pm 0.1\end{array}$ & $\begin{array}{l}6.7 \\
\pm 0.3\end{array}$ & $\begin{array}{l}6.8 \\
\pm 0.4\end{array}$ & 33 \\
\hline Athens (150) & $\begin{array}{l}4.6 \\
\pm 0.1\end{array}$ & $\begin{array}{l}4.8 \\
\pm 0.1\end{array}$ & $\begin{array}{l}6.0 \\
\pm 0.1\end{array}$ & $\begin{array}{l}6.1 \\
+0.1\end{array}$ & $\begin{array}{l}7.1 \\
\pm 0.3\end{array}$ & $\begin{array}{l}7.4 \\
\pm 0.6\end{array}$ & 34 \\
\hline Thessaloniki(100) & $\begin{array}{l}3.7 \\
\pm 0.2\end{array}$ & $\begin{array}{l}3.4 \\
\pm 0.4\end{array}$ & $\begin{array}{l}6.0 \\
\pm 0.2\end{array}$ & $\begin{array}{l}6.3 \\
\pm 0.2\end{array}$ & $\begin{array}{l}7.3 \\
+0.4\end{array}$ & $\begin{array}{l}8.2 \\
\pm 1.17\end{array}$ & 58 \\
\hline Thessaloniki (150) & $\begin{array}{l}4.3 \\
\pm 0.1\end{array}$ & $\begin{array}{l}4.3 \\
\pm 0.2\end{array}$ & $\begin{array}{l}6.6 \\
\pm 0.1\end{array}$ & $\begin{array}{l}6.7 \\
+0.2\end{array}$ & $\begin{array}{l}7.9 \\
+0.4\end{array}$ & $\begin{array}{l}8.6 \\
\pm 0.8\end{array}$ & 61 \\
\hline Patras (100) & $\begin{array}{l}4.7 \\
\pm 0.1\end{array}$ & $\begin{array}{l}4.9 \\
\pm 0.1\end{array}$ & $\begin{array}{l}5.7 \\
\pm 0.1\end{array}$ & $\begin{array}{l}5.8 \\
\pm 0.2\end{array}$ & $\begin{array}{l}6.9 \\
\pm 0.3\end{array}$ & $\begin{array}{l}6.7 \\
\pm 0.5\end{array}$ & 45 \\
\hline Patras (150) & $\begin{array}{l}5.2 \\
\pm 0.1\end{array}$ & $\begin{array}{l}5.3 \\
\pm 0.1\end{array}$ & $\begin{array}{l}6.3 \\
\pm 0.1\end{array}$ & $\begin{array}{l}6.4 \\
\pm 0.1\end{array}$ & $\begin{array}{l}7.5 \\
\pm 0.4\end{array}$ & $\begin{array}{l}8.2 \\
\pm 1.0\end{array}$ & 49 \\
\hline Corinth $(100)$ & $\begin{array}{l}4.7 \\
\pm 0.1\end{array}$ & $\begin{array}{l}5.2 \\
\pm 0.2\end{array}$ & $\begin{array}{l}5.8 \\
\pm 0.1\end{array}$ & $\begin{array}{l}6.1 \\
\pm 0.3\end{array}$ & $\begin{array}{l}6.9 \\
\pm 0.3\end{array}$ & $\begin{array}{l}6.8 \\
\pm 0.3\end{array}$ & 36 \\
\hline Corinth $(150)$ & $\begin{array}{l}5.0 \\
\pm 0.1\end{array}$ & $\begin{array}{l}5.3 \\
\pm 0.1\end{array}$ & $\begin{array}{l}6.1 \\
\pm 0.1\end{array}$ & $\begin{array}{l}6.2 \\
\pm 0.2\end{array}$ & $\begin{array}{l}7.1 \\
+0.3\end{array}$ & $\begin{array}{l}7.2 \\
\pm 0.4\end{array}$ & 29 \\
\hline Heraklion (100) & $\begin{array}{l}4.3 \\
\pm 0.1\end{array}$ & $\begin{array}{l}4.2 \\
\pm 0.2\end{array}$ & $\begin{array}{l}5.9 \\
\pm 0.1\end{array}$ & $\begin{array}{l}5.9 \\
\pm 0.2\end{array}$ & $\begin{array}{l}7.1 \\
\pm 0.4\end{array}$ & $\begin{array}{l}7.9 \\
\pm 1.9\end{array}$ & 54 \\
\hline Heraklion (150) & $\begin{array}{l}5.0 \\
\pm 0.1\end{array}$ & $\begin{array}{l}5.0 \\
\pm 0.1\end{array}$ & $\begin{array}{l}6.3 \\
\pm 0.1\end{array}$ & $\begin{array}{l}6.3 \\
\pm 0.2\end{array}$ & $\begin{array}{l}7.5 \\
\pm 0.4\end{array}$ & $\begin{array}{l}8.9 \\
\pm 1.9\end{array}$ & 52 \\
\hline Rodhos $(100)$ & $\begin{array}{l}4.4 \\
\pm 0.1\end{array}$ & $\begin{array}{l}4.1 \\
\pm 0.3\end{array}$ & $\begin{array}{l}6.0 \\
\pm 0.1\end{array}$ & $\begin{array}{l}6.1 \\
\pm 0.3\end{array}$ & $\begin{array}{l}7.2 \\
\pm 0.4\end{array}$ & $\begin{array}{l}9.2 \\
+3.3\end{array}$ & 64 \\
\hline Rodhos (150) & $\begin{array}{l}4.8 \\
\pm 0.1\end{array}$ & $\begin{array}{l}4.7 \\
\pm 0.1\end{array}$ & $\begin{array}{l}6.4 \\
\pm 0.1\end{array}$ & $\begin{array}{l}6.5 \\
\pm 0.2\end{array}$ & $\begin{array}{l}7.5 \\
\pm 0.4\end{array}$ & $\begin{array}{l}9.4 \\
\pm 2.0\end{array}$ & 39 \\
\hline Greece & $\begin{array}{l}6.2 \\
\pm 0.1\end{array}$ & $\begin{array}{l}6.4 \\
\pm 0.1\end{array}$ & $\begin{array}{l}7.1 \\
\pm 0.1\end{array}$ & $\begin{array}{l}7.2 \\
\pm 0.1\end{array}$ & $\begin{array}{l}8.2 \\
\pm 0.4\end{array}$ & $\begin{array}{l}8.7 \\
\pm 0.6\end{array}$ & 33 \\
\hline
\end{tabular}

* $m(1)$ and $X_{2}$ are estimated using eqns. (4) and (10) and $(\omega, u, \lambda)$ parameters of Table 1.

\section{Comparison of the methodologies}

Tables 1 and 2 immediately show the close relationship between results from the two methods. In places where the cumulative strain energy release graphs include at least one well defined cycle or periodicity of strain release then the parameters of the third type asymptotic distribution are well defined and have small uncertainties, examples are: Athens for $100 \mathrm{~km}$ and $150 \mathrm{~km}$ radii (Figs. 2a and c), similarly Corinth (Figs. 5a and c) and Patras for $100 \mathrm{~km}$ radius (Fig. 4a). In places where it is not clear if the periodic cycle of strain energy release has been completed we find the parameters are accompanied by larger uncertainties, examples here are: Thessaloniki 


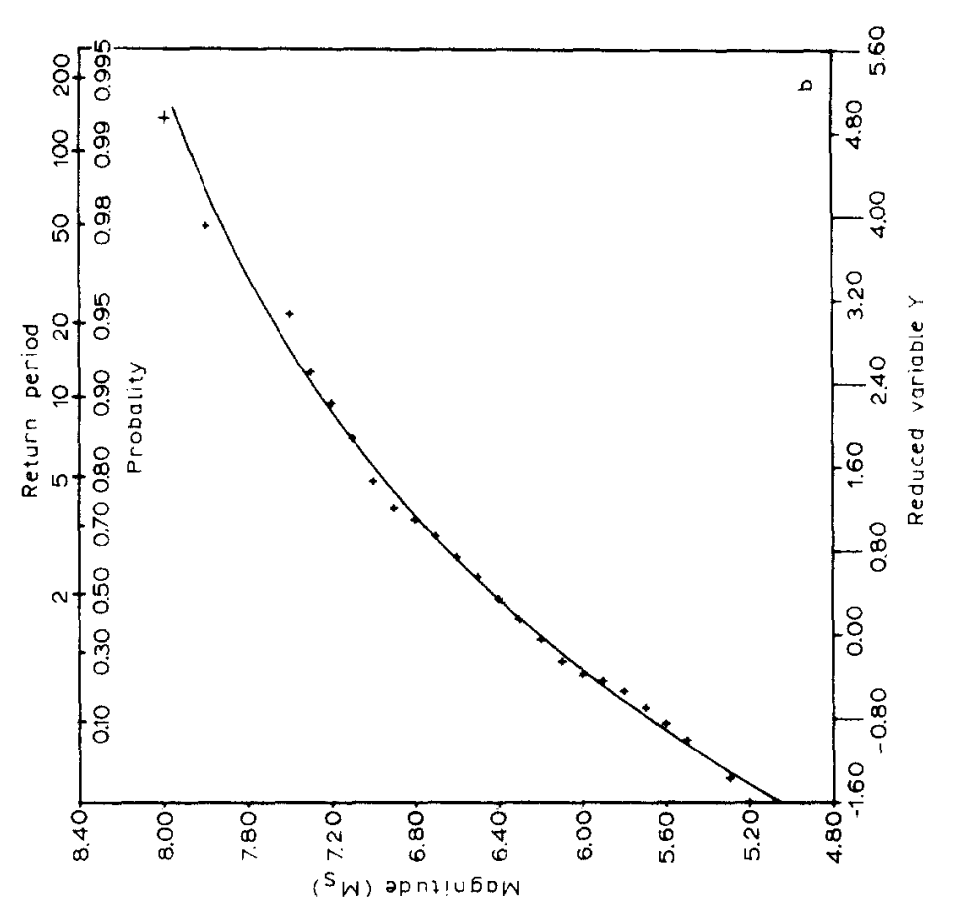

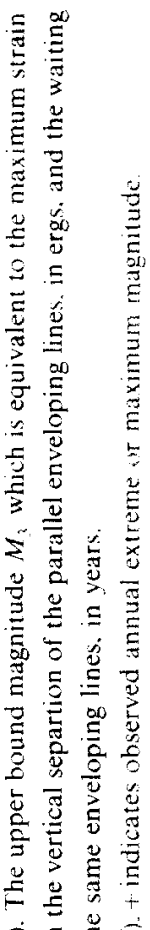

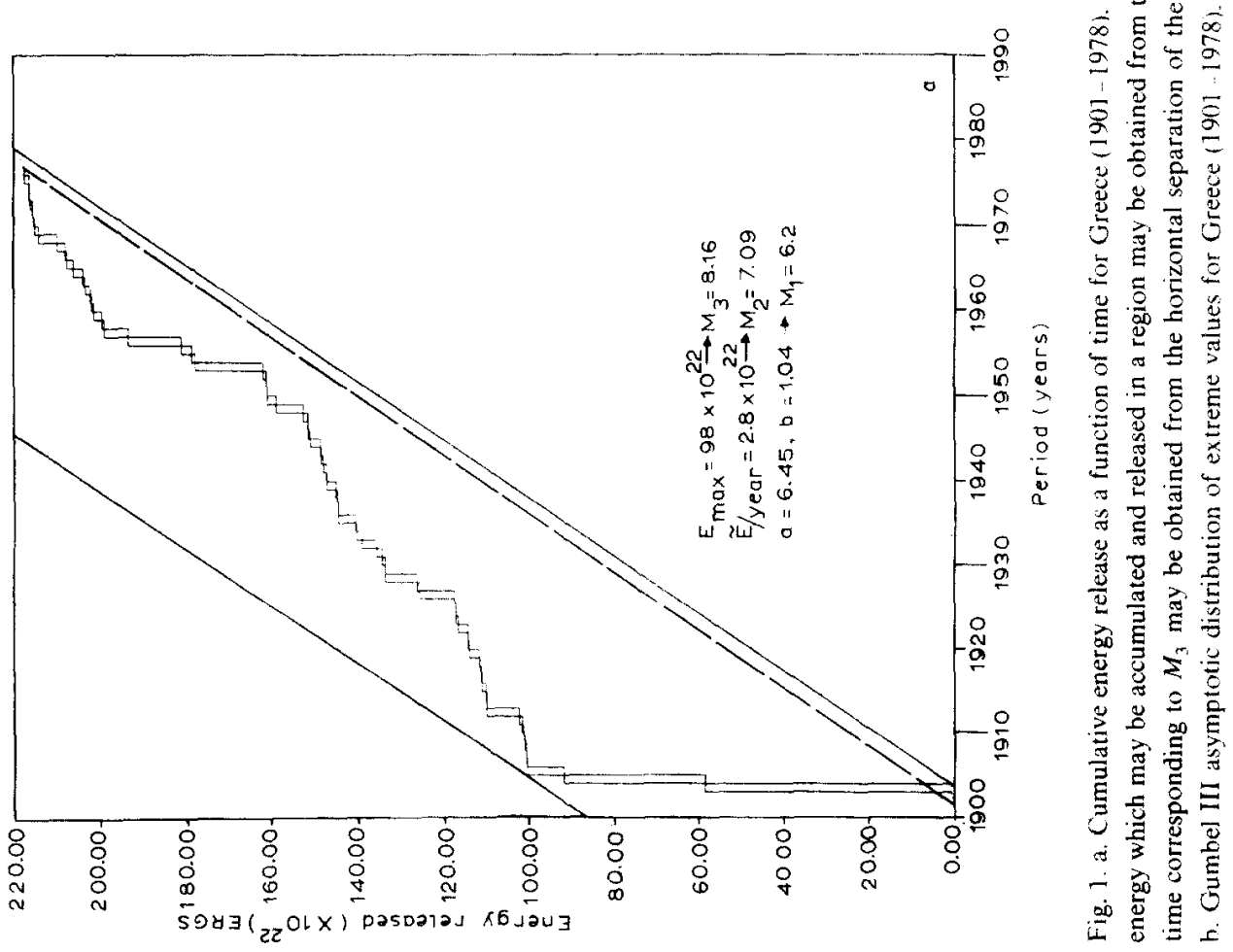


for $100 \mathrm{~km}$ and $150 \mathrm{~km}$ radii (Figs. $3 \mathrm{a}$ and c) and Rodhos for $100 \mathrm{~km}$ radius (Fig. 7a).

In almost all cases the magnitude distribution shows a remarkably good third type asymptotic behaviour. This is apparent from all the figures showing visually the Gumbel III curves fitted to the observed data points, as well as from the small values of reduced chi-square in Table 1.

Thessaloniki is seen to have the largest reduced chi-squared values and visually poorest fit for both $100 \mathrm{~km}$ and $150 \mathrm{~km}$ radii. Inspection of the observed data points in Figs. $3 b$ and $d$ may suggest that this is caused by the superposition of two natural but different populations of earthquakes. We have noted this elsewhere for both interplate seismicity in the Aleutians and Alaska region (Burton and Makropoulos. 1983) as did Duda (1965), and also for intraplate seismicity in the New Madrid zone of the eastern U.S.A. (Burton et al., 1983). It is not surprising that there is considerable debate about the tectonics of Thessaloniki and the North Aegean (Makris, 1976, 1978; McKenzie, 1978; Papazachos, 1976a, b).

\section{Seismic hazard}

The Gumbel III parameters of Table 1 are used first to estimate the average return period in years for earthquake magnitudes ( $M_{\mathrm{s}}$ scale) $m=5.0$ to 8.0 in half magnitude steps, see Table 3 . The number of exceedances expected during the next 50 and 100 years for the same magnitude thresholds are listed in Tables 4 and 5 . These results for Greece as a whole and the city of Athens are chosen as representative and are discussed in detail below, whereas the seismic hazard parameters for the other five cities are merely tabulated although they can be viewed in similar detail.

\section{Discussion of seismic hazard in Greece as a whole}

The upper bound to earthquake magnitudes is found by two methodologies to be $M_{3}=8.16 \pm 0.43$ or $\omega=8.73 \pm 0.65$ for the strain energy release and Gumbell III methods respectively. During the 78 years of instrumental data the maximum earthquake magnitude had a value of 8.0 (1903, August 11), although there are reasons to believe this magnitude is an overestimate (Ambraseys, 1981). Galanopoulos (1972) using the graphical method for strain energy release estimated the upper bound to be $m=8 \frac{1}{2}$. When the seismic history of the area is considered (Richter, 1958; Galanopoulos, 1960, 1961; Lomnitz, 1974) an upper bound surface wave magnitude over 8 is acceptable, and it is seen above that the "waiting time" associated with the accumulation of strain energy is 33 years (see Fig. 1a).

The most probable annual maximum is $m(1)=6.4 \pm 0.1$. Galanopoulos (1972) and Comninakis (1975) using the Gutenberg-Richter frequency-magnitude law, estimated the mode as 6.5 and 6.4 respectively. The mean annual rate of energy release corresponds to an earthquake with magnitude $m=7.2 \pm 0.1$. An earthquake with magnitude greater than or equal to 5.5 is expected to be the annual maximum 

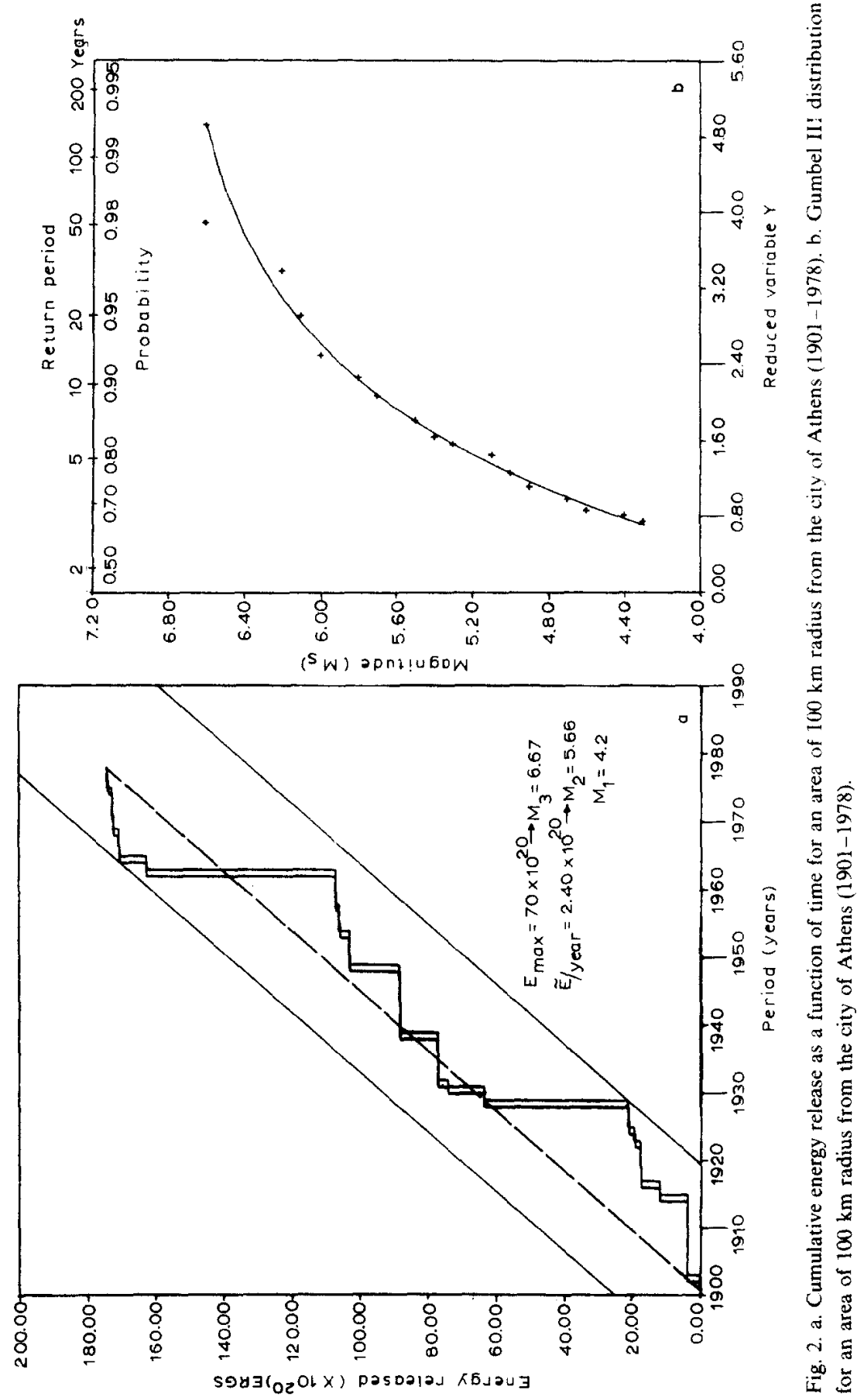


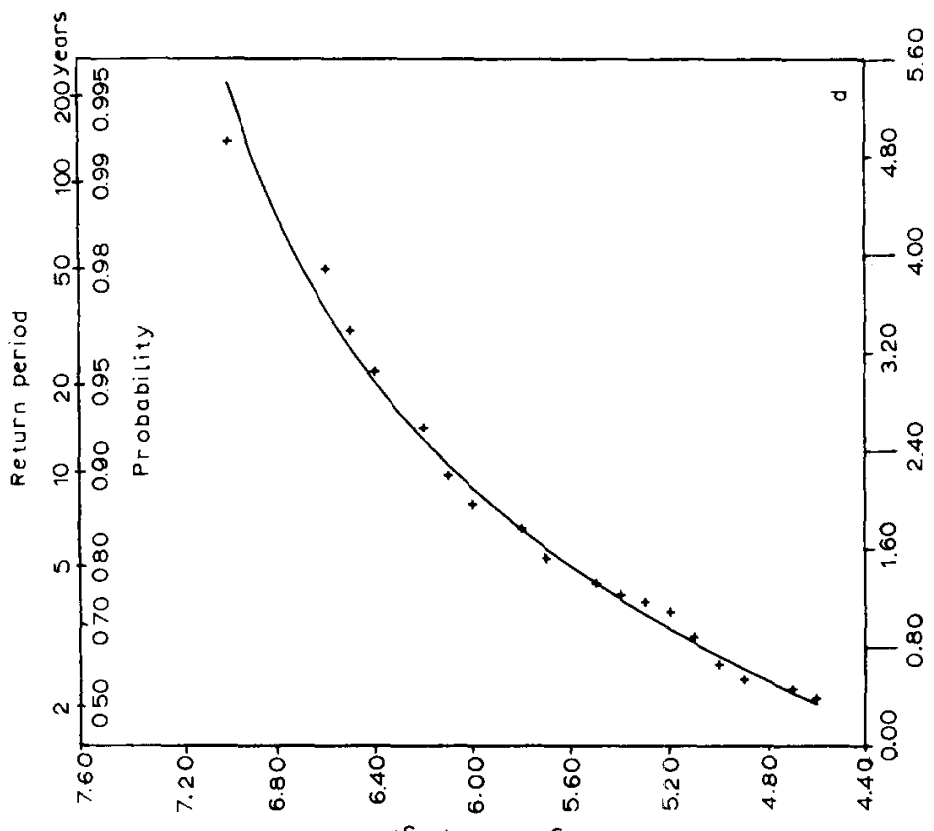

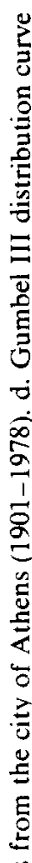

( $S_{W}$ apnz!u

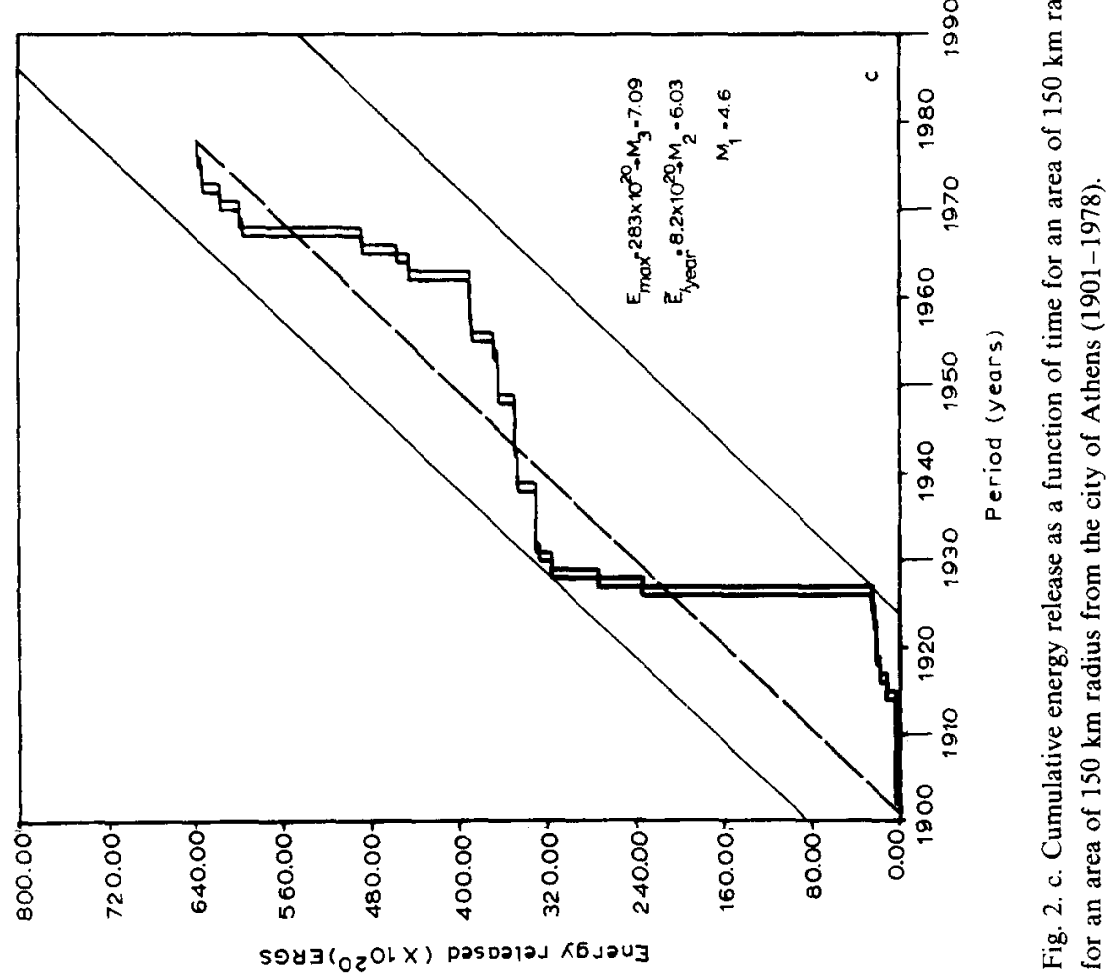



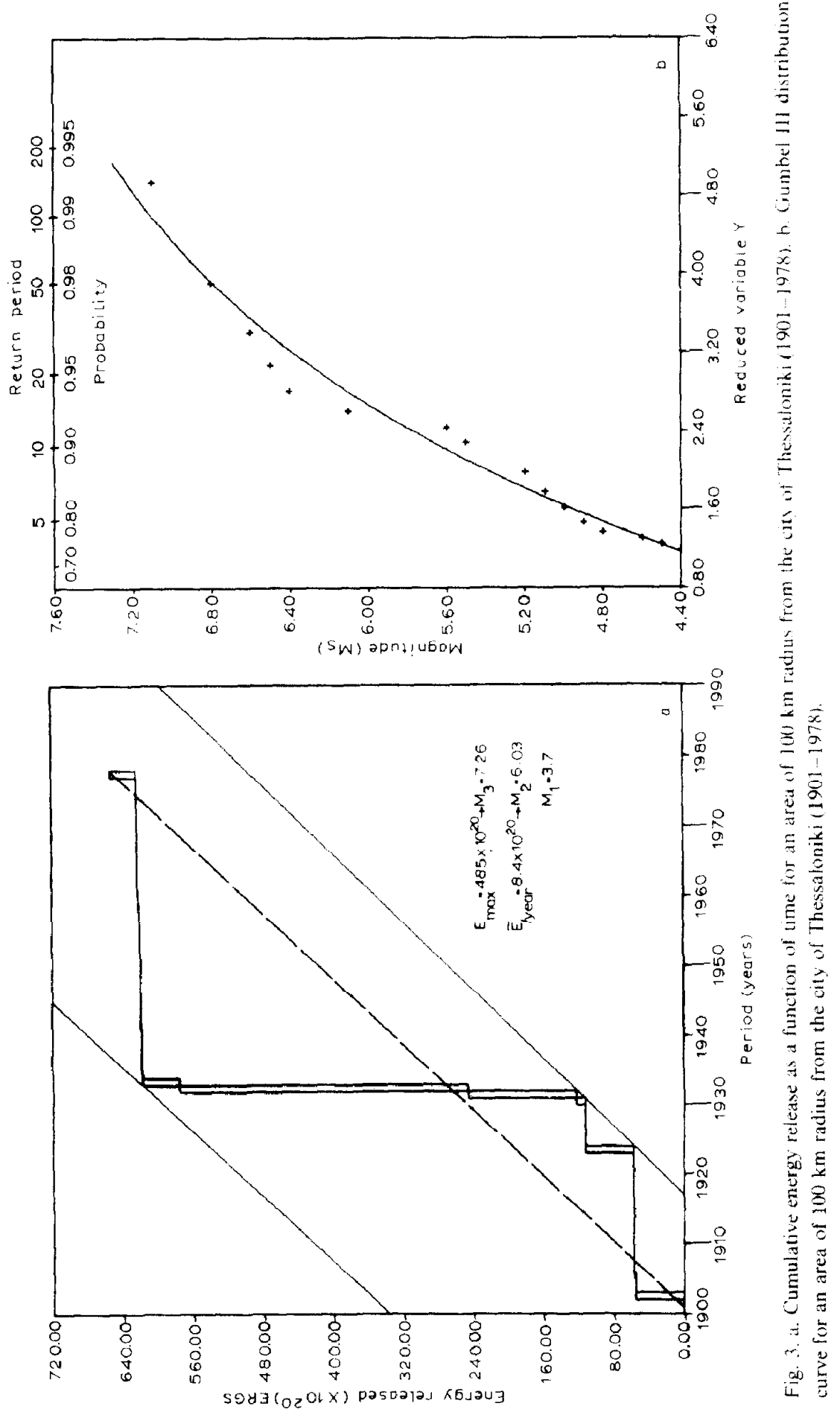

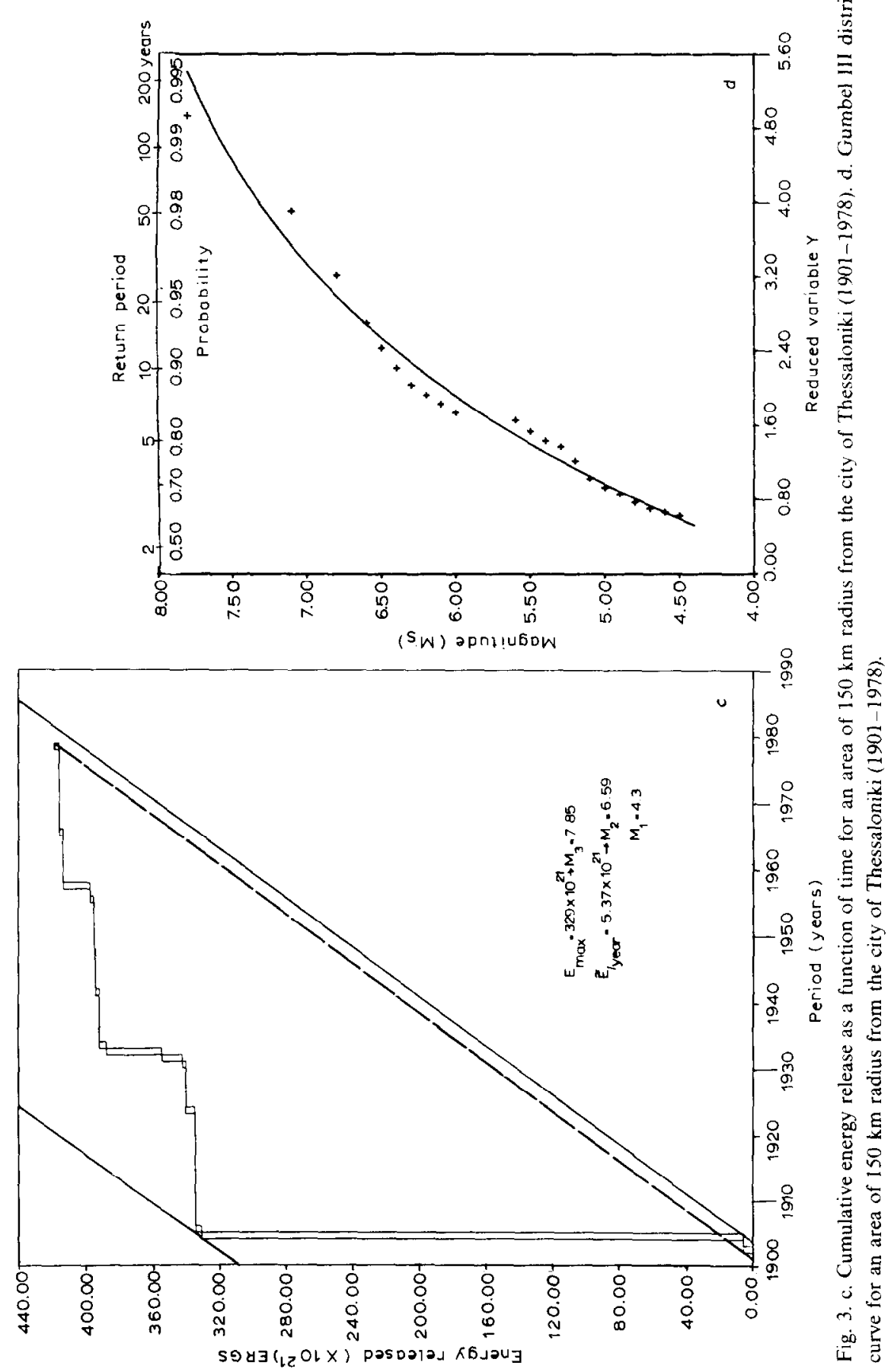

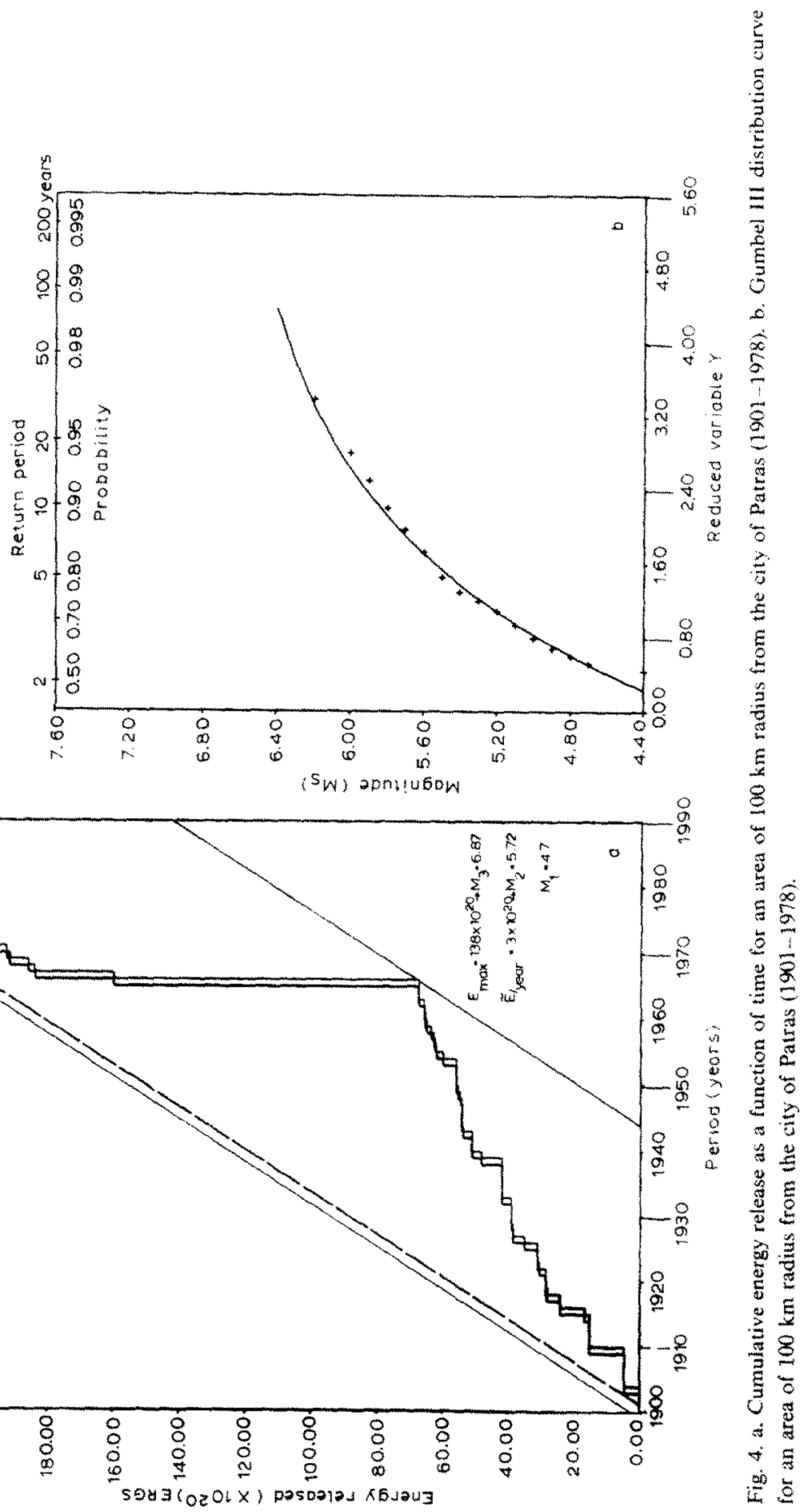

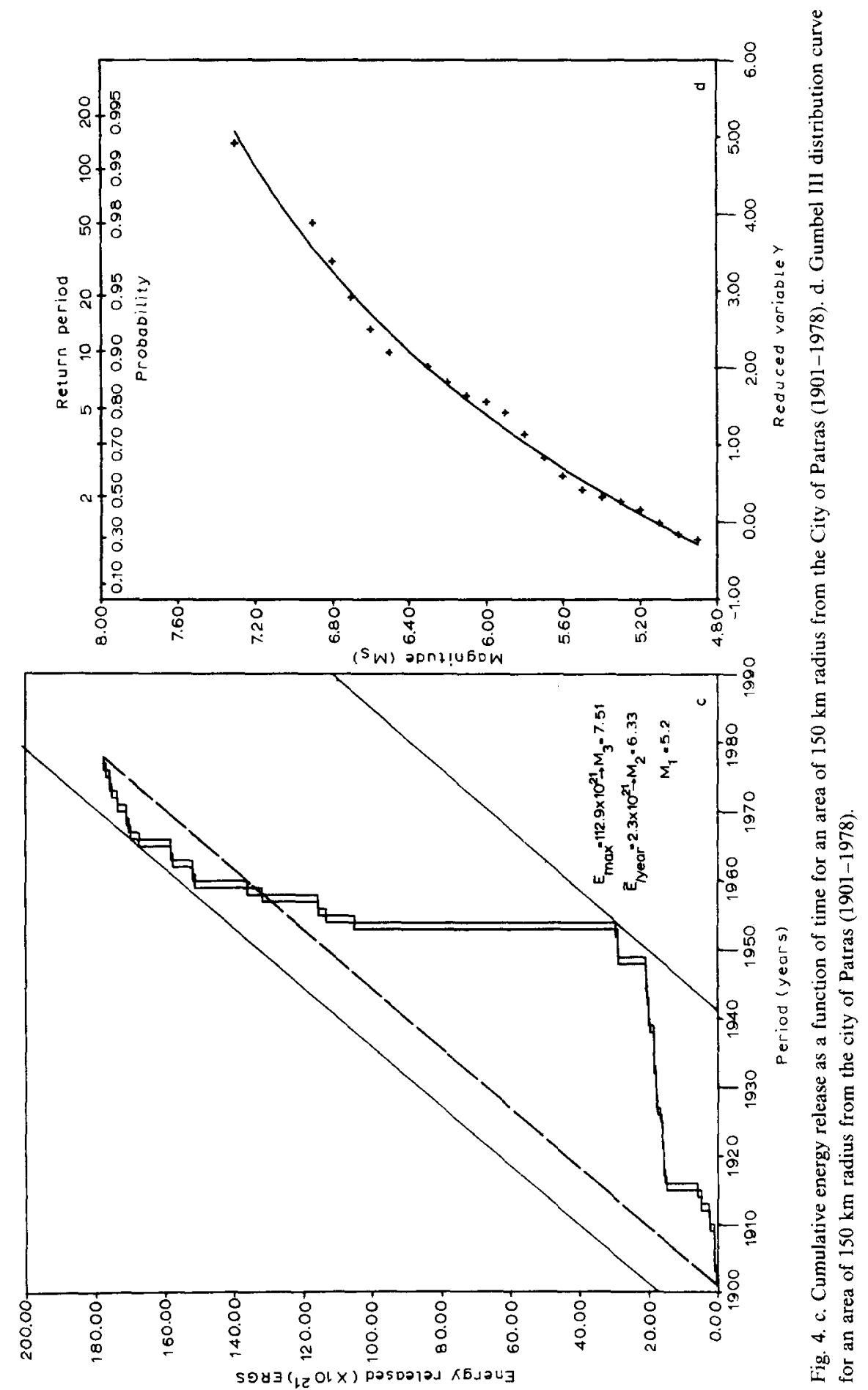

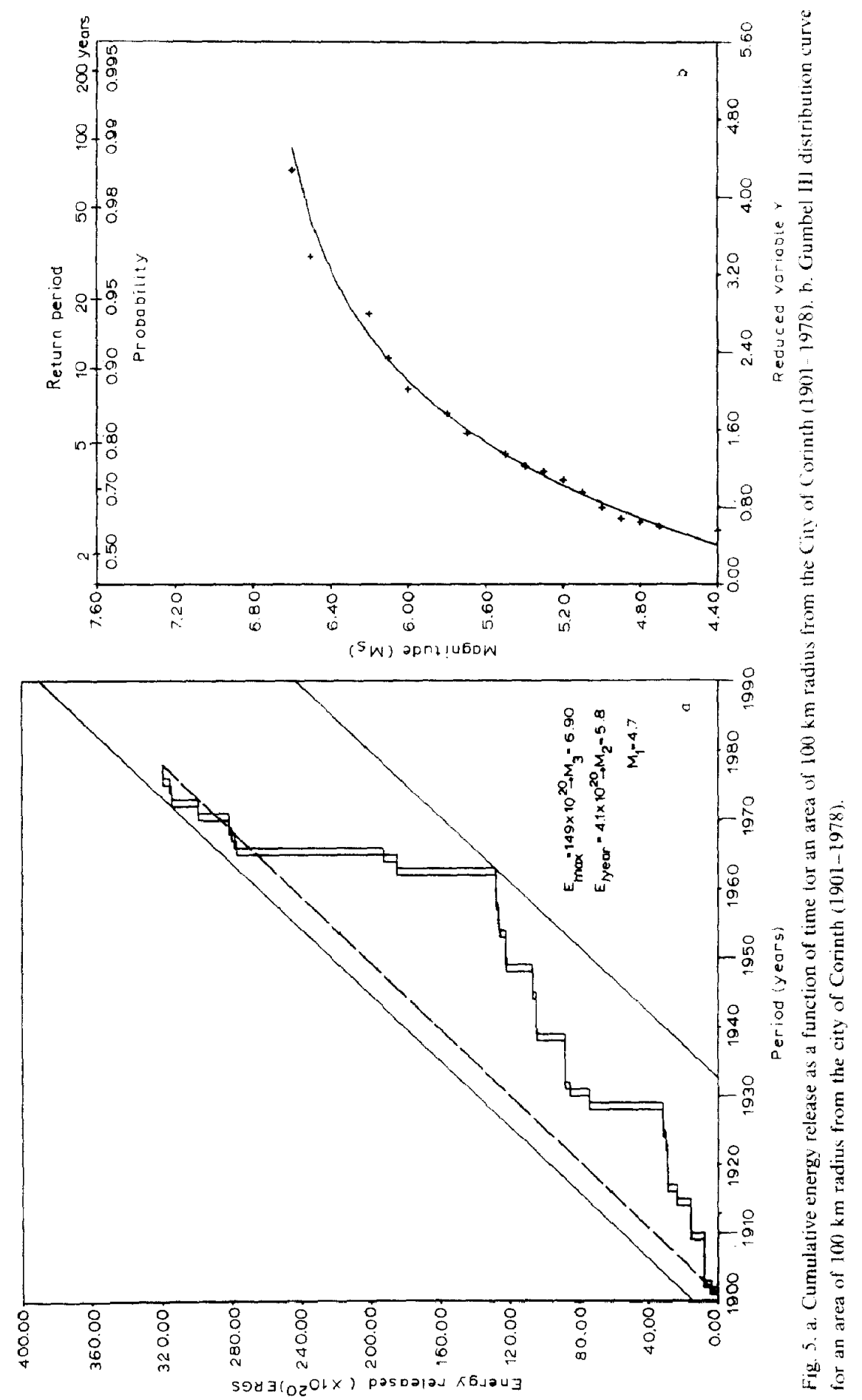

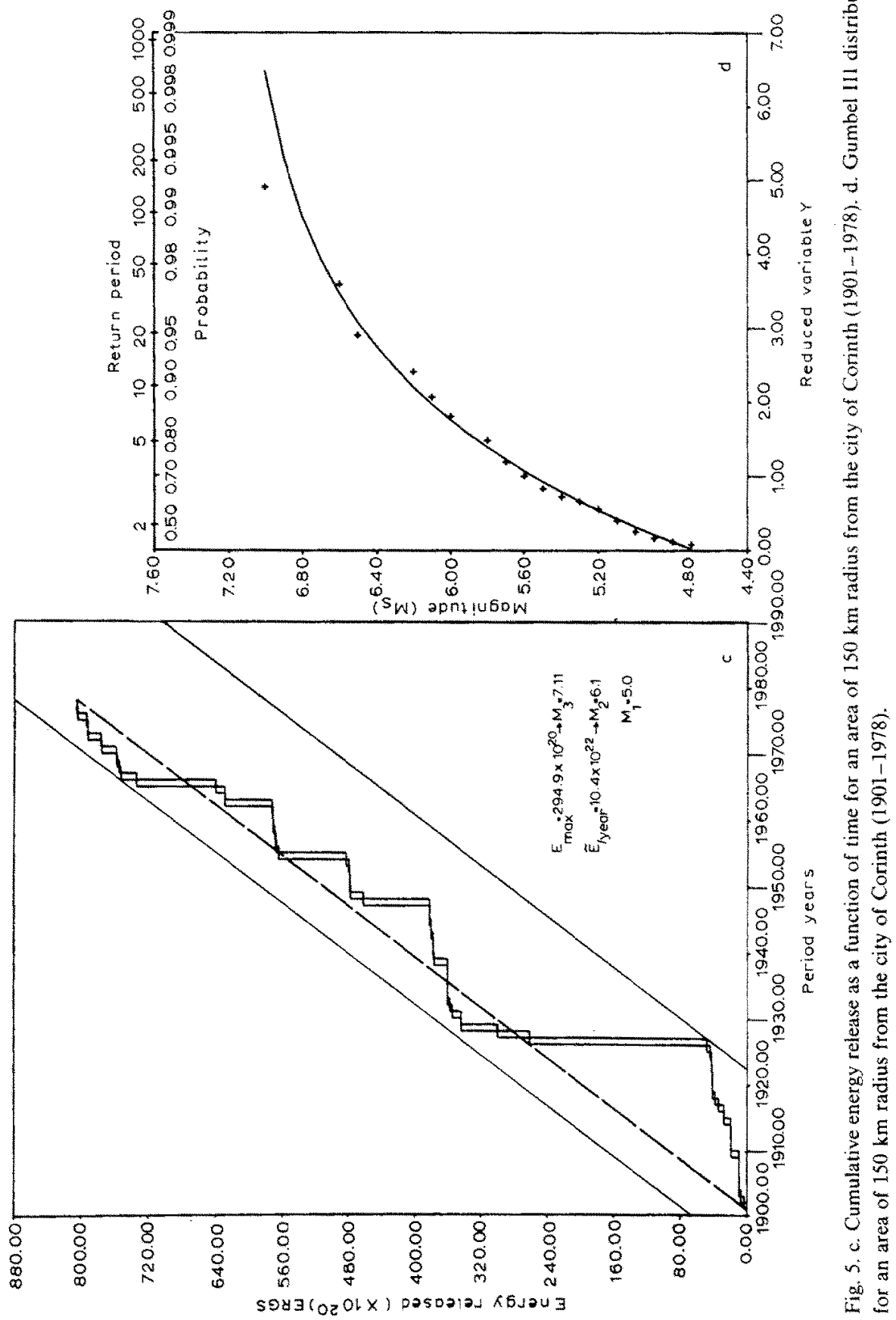

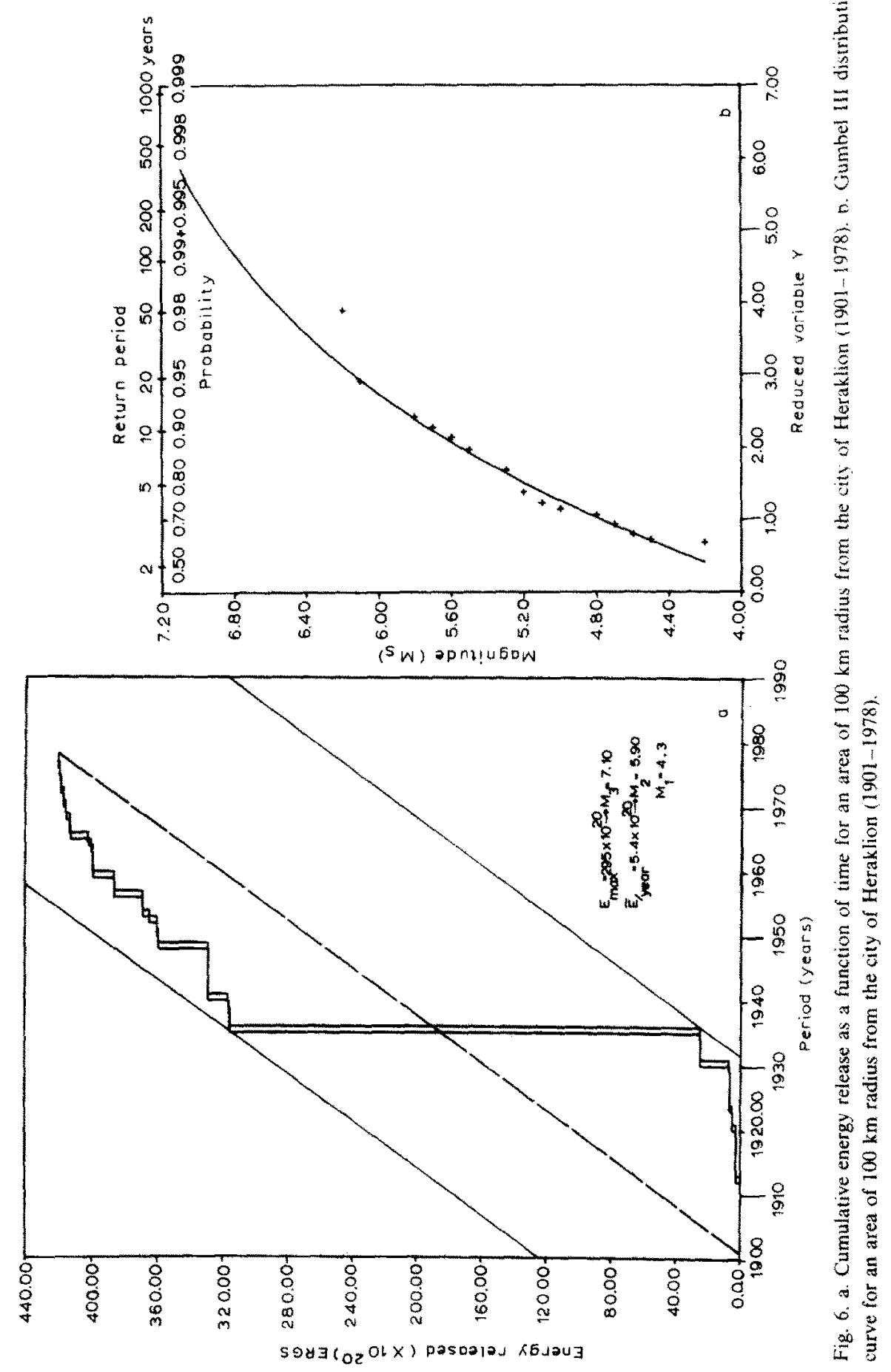

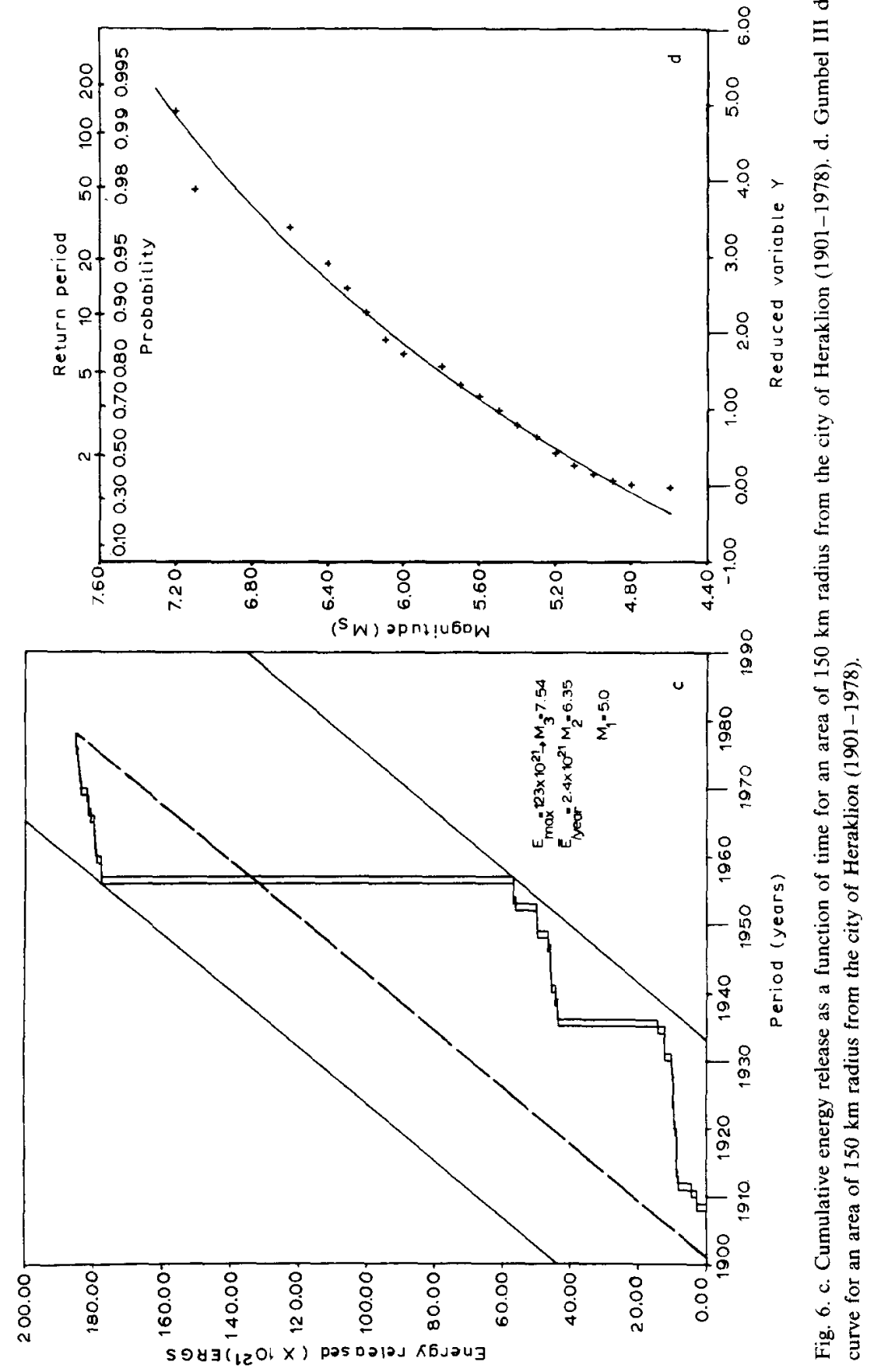

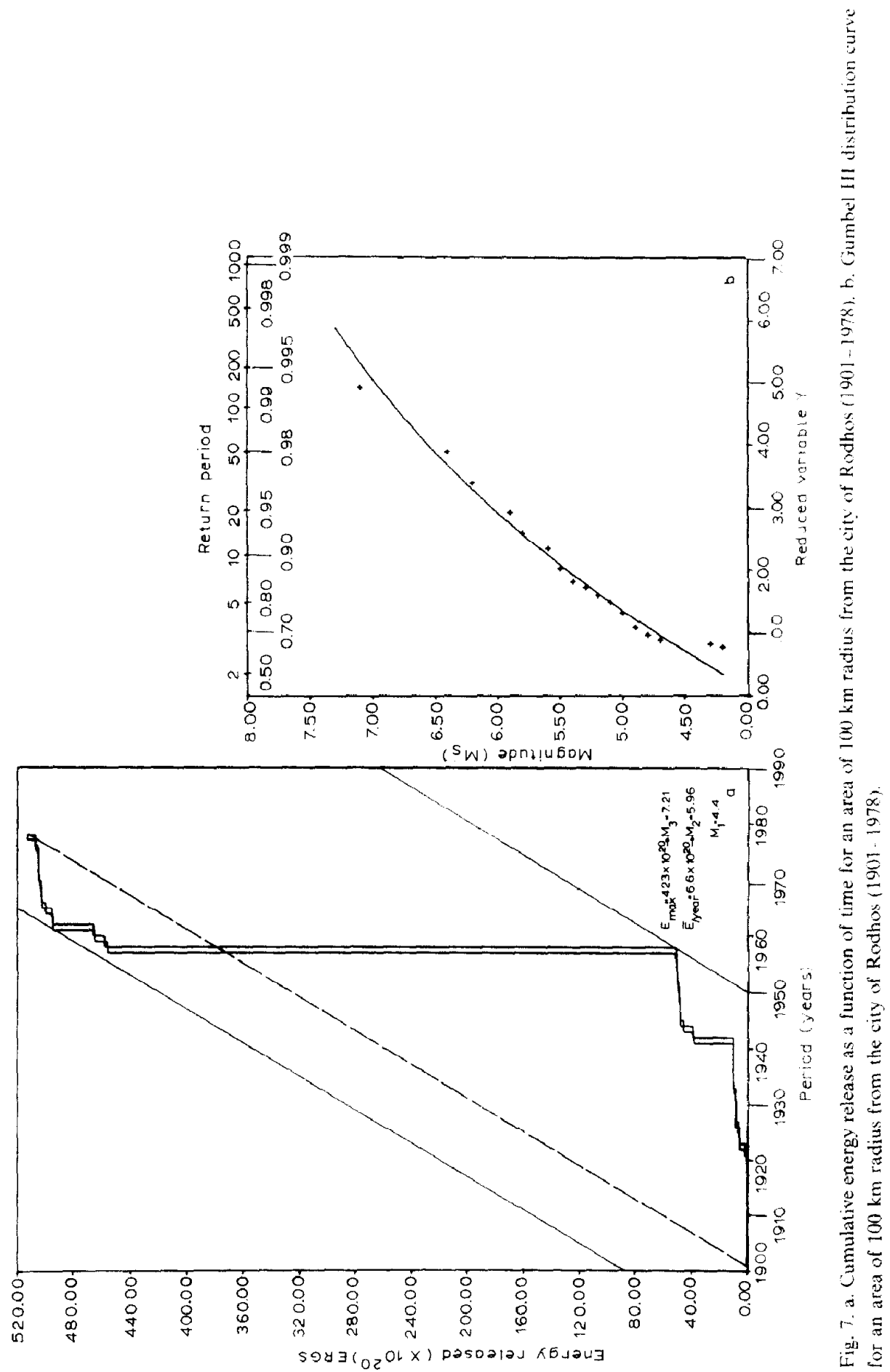


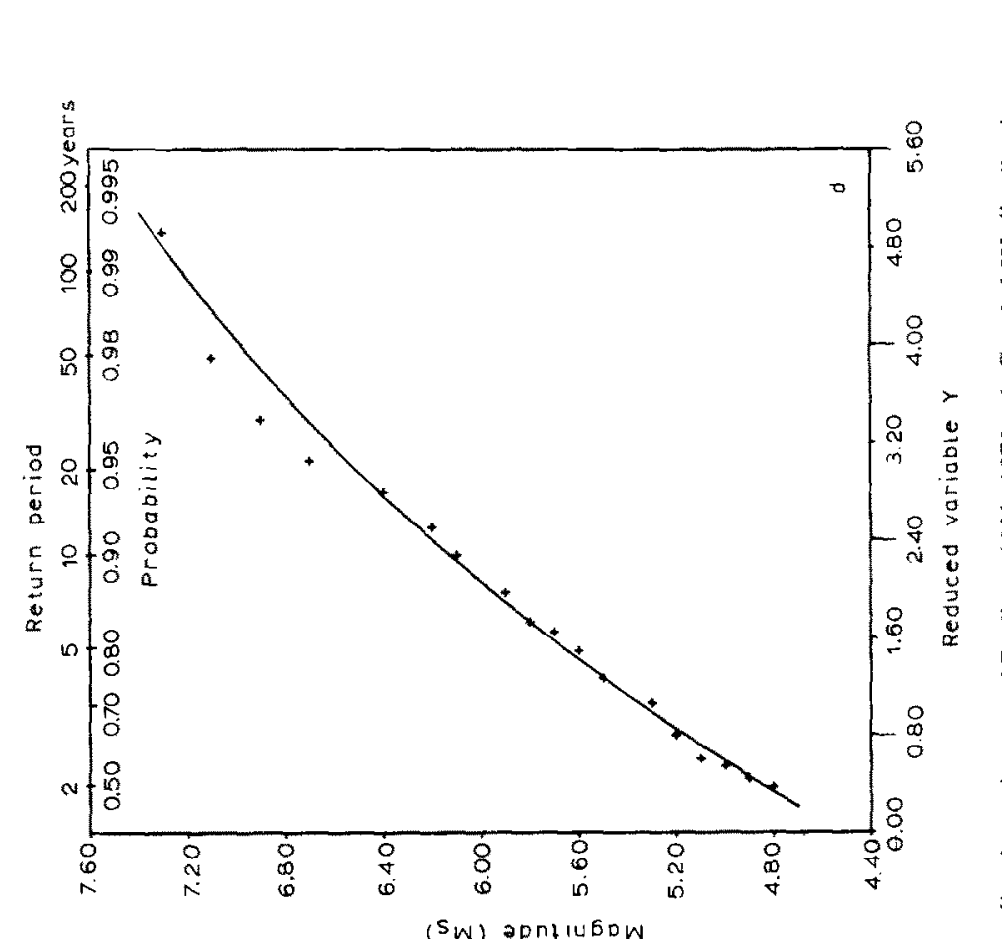

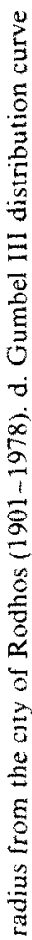

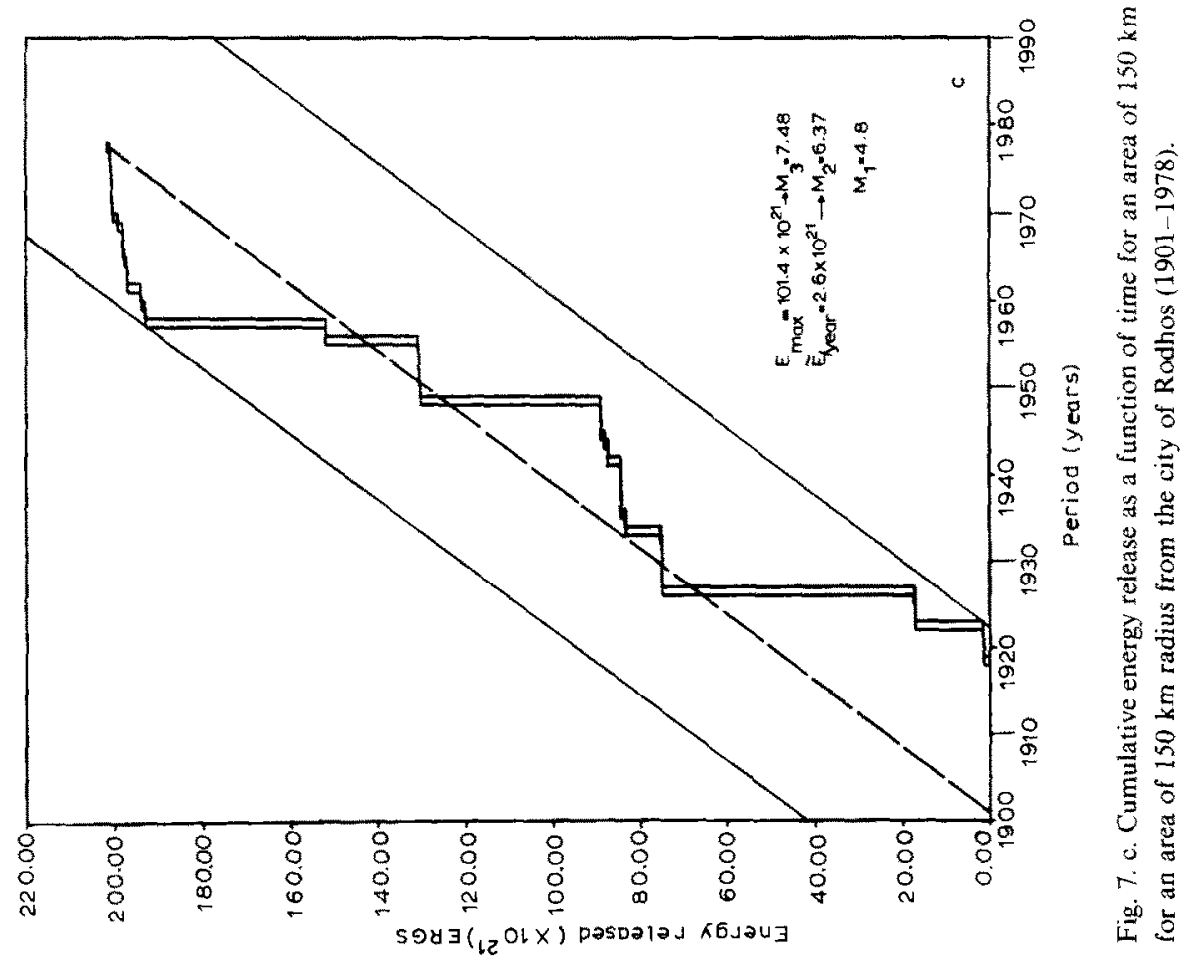


TABLE 3

Return period (years), for a given magnitude $M_{s}$

\begin{tabular}{|c|c|c|c|c|c|c|c|}
\hline \multirow[t]{2}{*}{ Place } & \multicolumn{7}{|c|}{ Return period (years) } \\
\hline & $M_{\mathrm{s}}=5.0$ & 5.5 & 6.0 & 6.5 & 7.0 & 7.5 & 8.0 \\
\hline Athens $(100)$ & 4.1 & 6.6 & 14.3 & 71.1 & -. & - & \\
\hline Athens (150) & 2.6 & 4.3 & 8.7 & 26.0 & 222.9 & - & \\
\hline Thessaloniki (100) & 5.7 & 8.7 & 15.0 & 30.0 & 77.8 & 343.6 & \\
\hline Thessaloniki (150) & 3.2 & 4.6 & 7.3 & 13.2 & 28.8 & 86.2 & 530.6 \\
\hline Patras $(100)$ & 2.8 & 5.2 & 14.3 & 184.1 & -. & - & \\
\hline Patras (150) & 1.4 & 2.3 & 4.6 & 12.3 & 49.8 & 442.2 & \\
\hline Corinth (100) & 2.9 & 4.4 & 8.7 & 42.9 & - & - & \\
\hline Corinth (150) & 1.9 & 3.1 & 6.4 & 22.5 & 654.0 & - & \\
\hline Heraklion (100) & 4.1 & 7.4 & 16.0 & 46.1 & 222.2 & - & \\
\hline Heraklion (150) & 1.8 & 3.2 & 6.9 & 19.1 & 69.3 & 378.8 & \\
\hline Rodhos (100) & 4.4 & 8.6 & 18.9 & 49.3 & 156.4 & 664.3 & .. \\
\hline Rodhos (150) & 2.6 & 4.1 & 8.3 & 19.8 & 57.3 & 216.1 & \\
\hline Greece & 1.0 & 1.1 & 1.3 & 2.4 & 5.5 & 21.9 & 198.4 \\
\hline
\end{tabular}

TABLE 4

The number of exceedances expected during the next 50 years as a function of magnitude $M_{\mathrm{S}}$

\begin{tabular}{|c|c|c|c|c|c|c|c|c|}
\hline \multirow[t]{2}{*}{ Place } & \multirow[b]{2}{*}{$M_{\mathrm{s}}=$} & \multicolumn{7}{|c|}{ Number of exceedances } \\
\hline & & 5.0 & 5.5 & 6.0 & 6.5 & 7.0 & 7.5 & 8.0 \\
\hline Athens $(100)$ & & $12-13$ & $7-8$ & $3-4$ & $0-1$ & & & \\
\hline Athens $(150)$ & & $19-20$ & $11-12$ & $5-6$ & $1-2$ & - & - & \\
\hline Thessaloniki (100) & & $8-9$ & $5-6$ & $3-4$ & $1-2$ & $0-1$ & - & \\
\hline Thessaloniki (150) & & $15-16$ & $10-11$ & $6-7$ & $1-4$ & $1-2$ & $0-1$ & \\
\hline Patras (100) & & $17-18$ & $9-10$ & $3-4$ & 0.1 & - & - & \\
\hline Patras (150) & & $34-35$ & $21-22$ & $10-11$ & $4-5$ & $1-2$ & - & \\
\hline Corinth (100) & & $17-18$ & $11-12$ & $5+6$ & $1-2$ & - & - & - \\
\hline Corinth (150) & & $25-26$ & $16-17$ & $7-8$ & $2-3$ & - & - & \\
\hline Heraklion (100) & & $12-13$ & $6-7$ & $3-4$ & $1-2$ & $0-1$ & - & \\
\hline Heraklion (150) & & $28-29$ & $15-16$ & $7-8$ & $2-3$ & $0-1$ & - & - \\
\hline Rodhos (100) & & $11-12$ & $5-6$ & $2-3$ & $1-2$ & - & - & \\
\hline Rodhos (150) & & $19-20$ & $12-13$ & $6-7$ & $2-3$ & $0-1$ & - & - \\
\hline Greece & & $49-50$ & $47-48$ & $37-38$ & $20-21$ & $9-10$ & $2-3$ & $0-1$ \\
\hline
\end{tabular}


TABLE 5

The number of exceedances expected during the next 100 years as a function of magnitude $M_{\mathrm{s}}$

\begin{tabular}{|c|c|c|c|c|c|c|c|c|}
\hline \multirow[t]{2}{*}{ Place } & \multicolumn{7}{|c|}{ Number of exceedances } & \multirow{2}{*}{$\begin{array}{l}\text { Max. } M_{s} \\
\text { observed } \\
\text { (78 years) }\end{array}$} \\
\hline & $M_{\mathrm{s}}=5.0$ & 5.5 & 6.0 & 6.5 & 7.0 & 7.5 & 8.0 & \\
\hline Athens $(100)$ & $24-25$ & $15-16$ & $7-8$ & $1-2$ & - & - & - & 6.6 \\
\hline Athens $(150)$ & $38-39$ & $23-24$ & $11-12$ & $3-4$ & $0-1$ & - & - & 7.0 \\
\hline Thessaloniki (100) & $17-18$ & $11-12$ & $6-7$ & $3-4$ & $1-2$ & - & - & 7.1 \\
\hline Thessaloniki (150) & $31-32$ & $21-22$ & $13-14$ & $7-8$ & $3-4$ & $0-1$ & - & 7.8 \\
\hline Patras (100) & $35-36$ & $19-20$ & $7-8$ & $0-1$ & - & - & - & 6.6 \\
\hline Patras (150) & $68-69$ & $43-44$ & $21-22$ & $8-9$ & $2-3$ & $0-1$ & - & 7.3 \\
\hline Corinth (100) & $34-35$ & $22-23$ & $11-12$ & $2-3$ & - & - & - & 6.6 \\
\hline Corinth $(150)$ & $51-52$ & $32-33$ & $15-6$ & $4-5$ & $0-1$ & - & - & 7.0 \\
\hline Heraklion (100) & $24-25$ & $13-14$ & $6-7$ & $2-3$ & $0-1$ & - & - & 7.1 \\
\hline Heraklion (150) & $56-57$ & $31-32$ & $14-15$ & $5-6$ & $1-2$ & $0-1$ & - & 7.2 \\
\hline Rodhos $(100)$ & $22-23$ & $11-12$ & $5-6$ & $2-3$ & $0-1$ & - & - & 7.1 \\
\hline Rodhos (150) & $38-39$ & $24-25$ & $12-13$ & $5-6$ & $1-2$ & $0-1$ & - & 7.3 \\
\hline Greece & $99-100$ & $94-95$ & $75-76$ & $40-41$ & $18-19$ & $4-5$ & $0-1$ & 8.0 \\
\hline
\end{tabular}

magnitude almost every year (return period $=1.06$ years). The period required for an earthquake with magnitude greater than or equal to 7.0 to be observed as an annual maximum is 5.5 years, whereas an interval of about 200 years is needed for an earthquake with magnitude greater than or equal to the largest observed in the region ( $m=8.0)$ to be an annual extreme magnitude. However, the return period for an earthquake with magnitude 7.5 is only 22 years.

The number of exceedances of given maximum magnitude earthquakes which is predicted for Greece, along with the number observed, during the 78 year sample period, is shown in Table 6 . This shows that for both low and high magnitudes the predicted numbers agree with the maximum magnitudes observed. The close agreement between observed and predicted extreme magnitudes not only illustrates the plausibility of the method, but also shows that the sample period considered is long enough to obtain statistically stable estimates.

\section{Discussion of seismic hazard for Athens}

The third type asymptote is well developed for Athens (Figs. 2b and d), implying small uncertainties for the upper bound magnitudes $\omega, \omega=6.80 \pm 0.39(100 \mathrm{~km})$ or $\omega=7.35 \pm 0.58(150 \mathrm{~km})$. These values also agree well with $M_{3}$ from strain energy release (Figs. 2a and c): $M_{3}=6.7 \pm 0.3(100 \mathrm{~km})$ or $M_{3}=7.1 \pm 0.3(150 \mathrm{~km})$, and the latter values have associated "waiting times" of 33 and 34 years respectively. The 


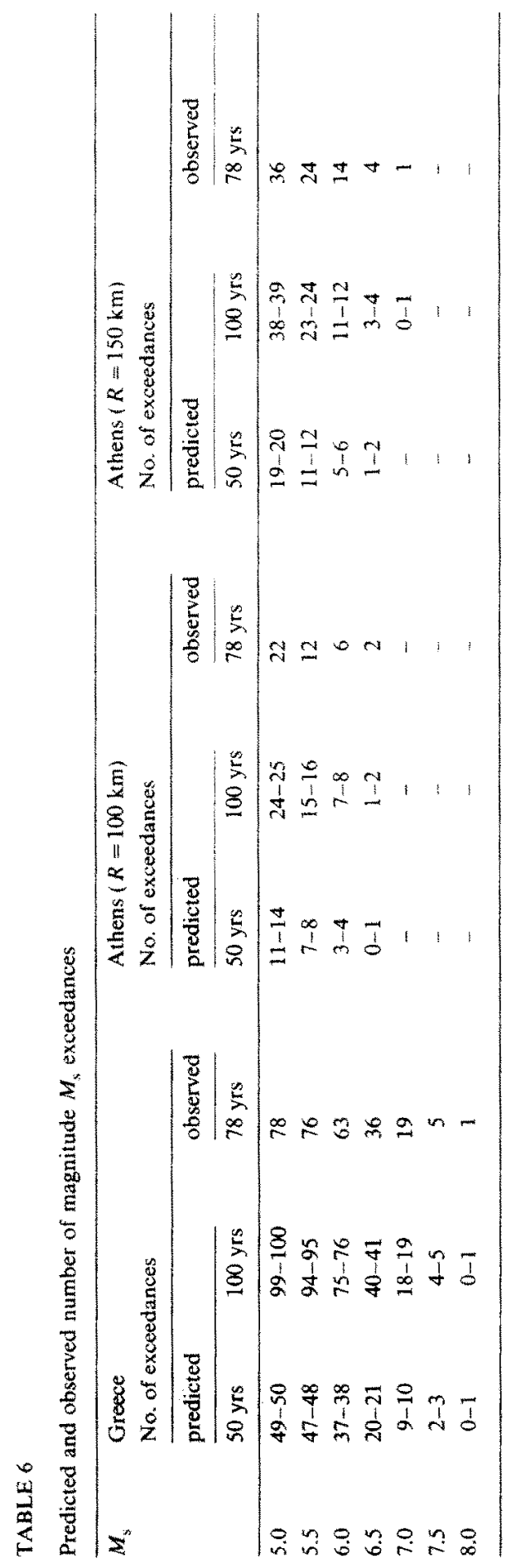




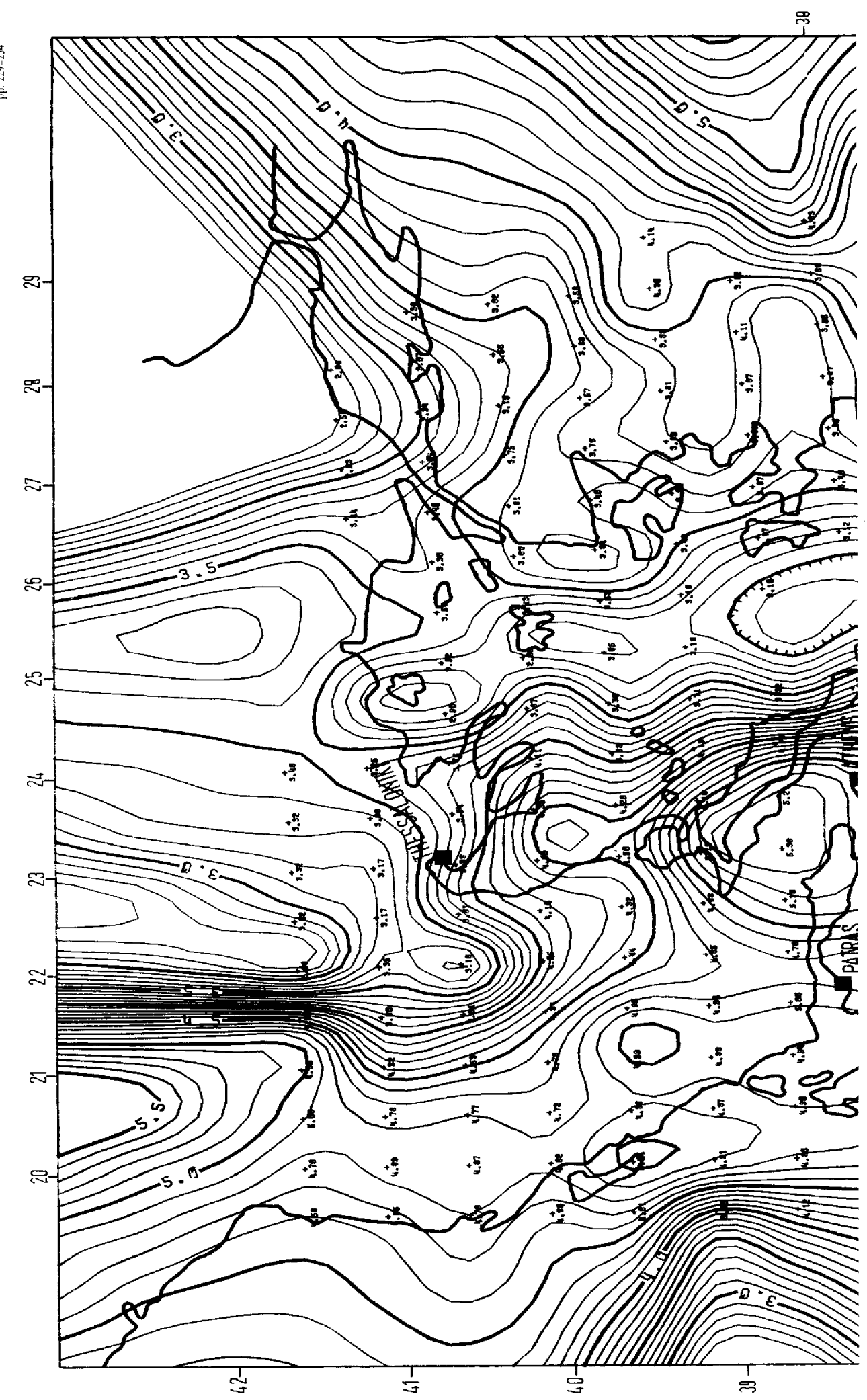




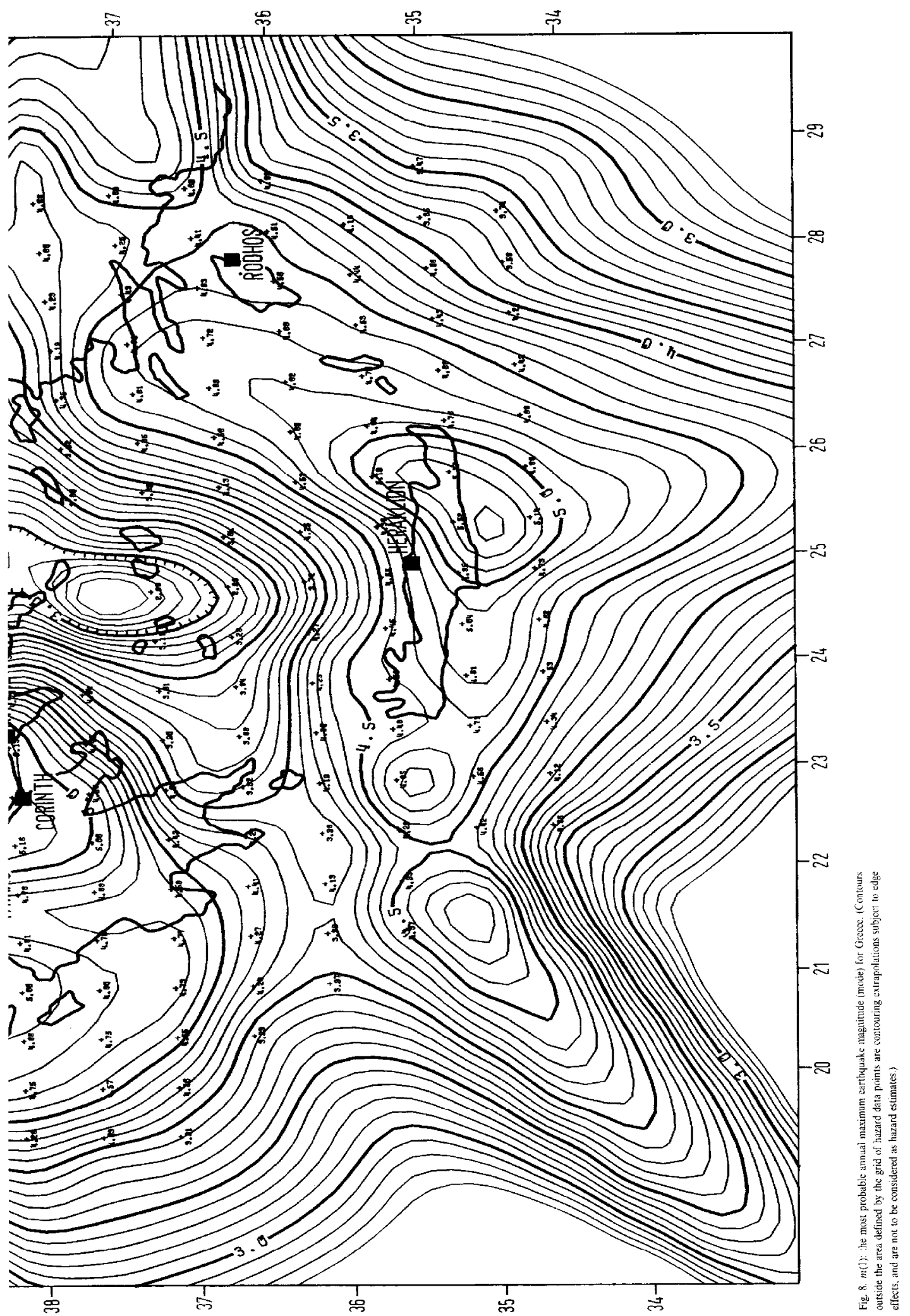




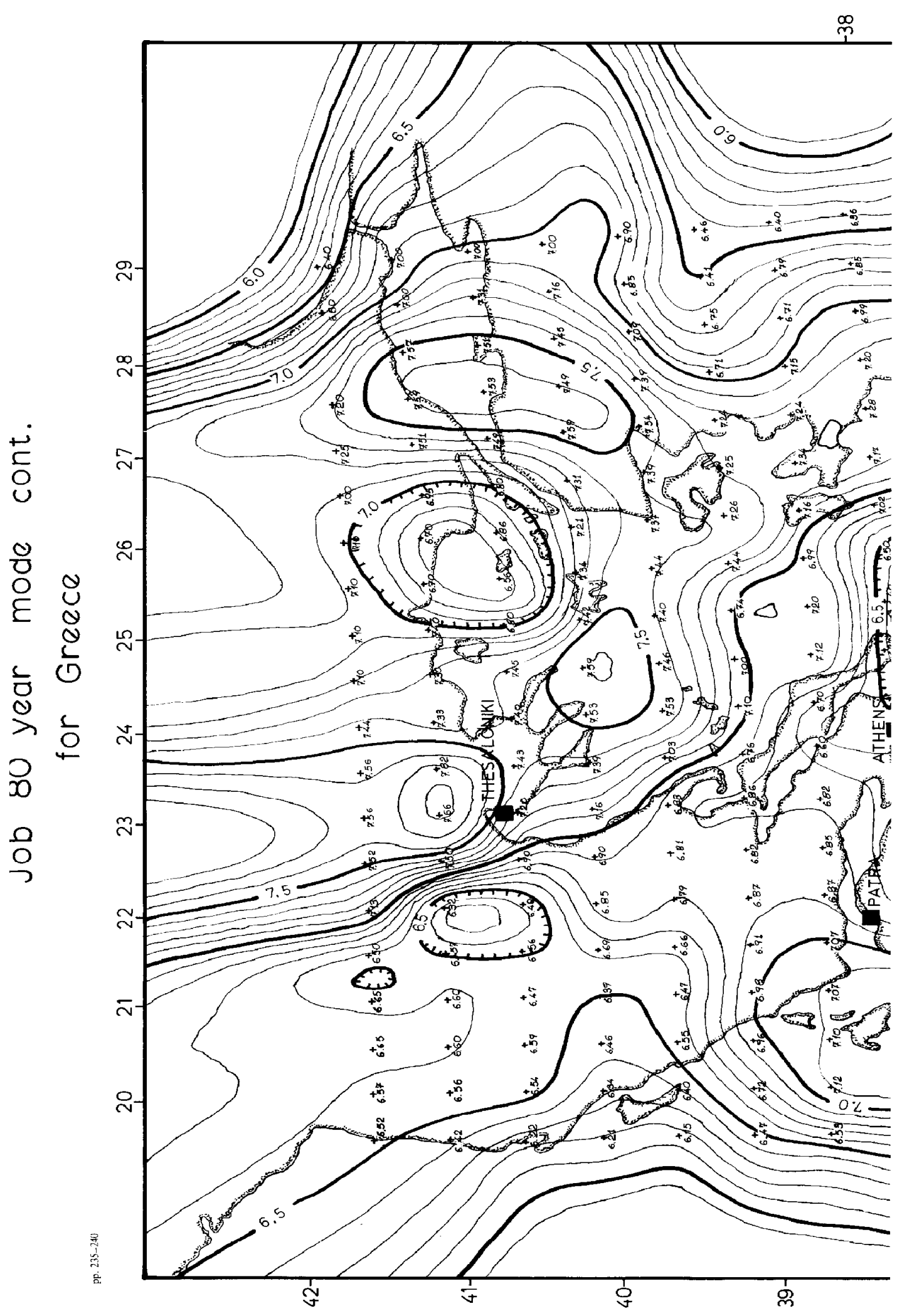




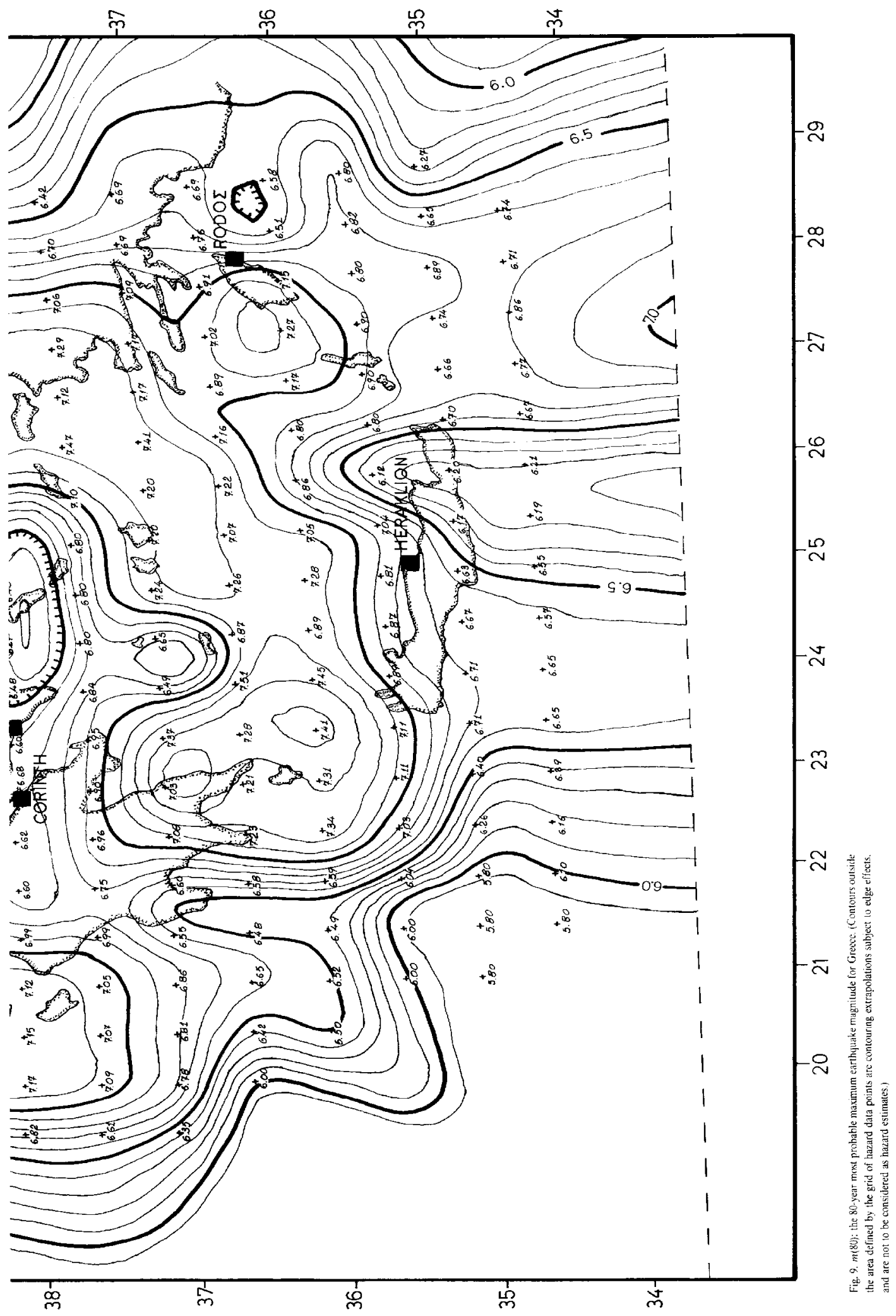




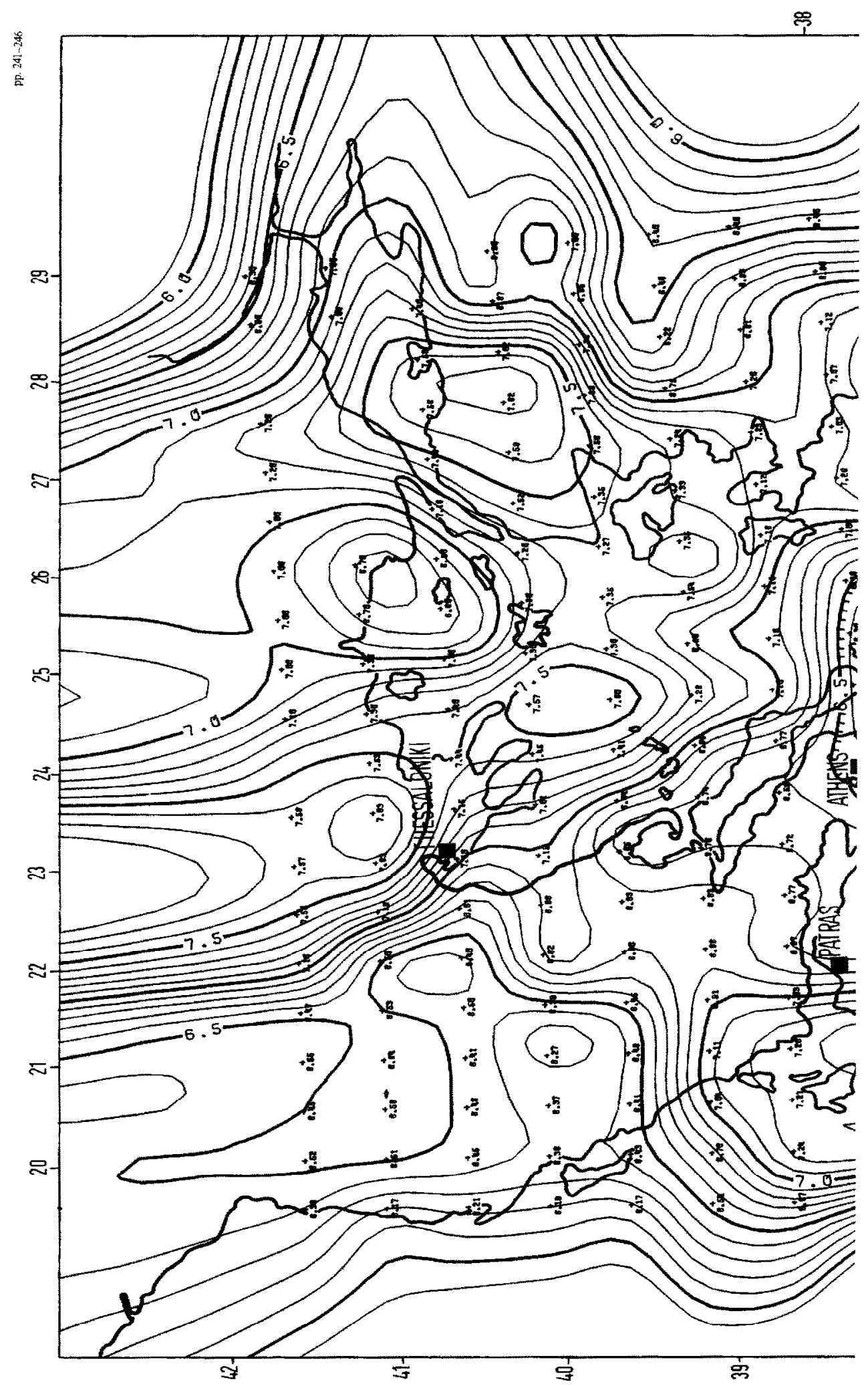




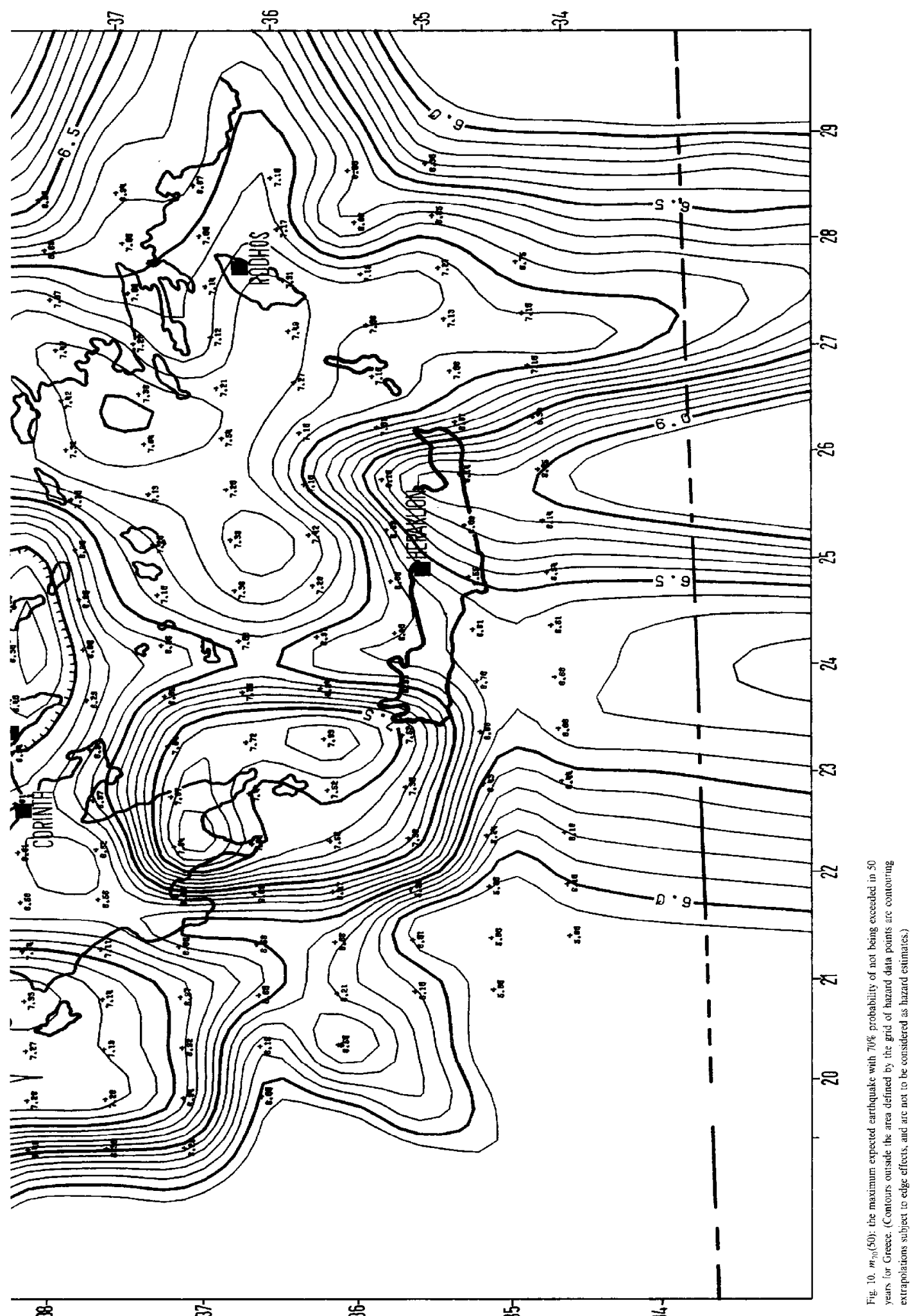




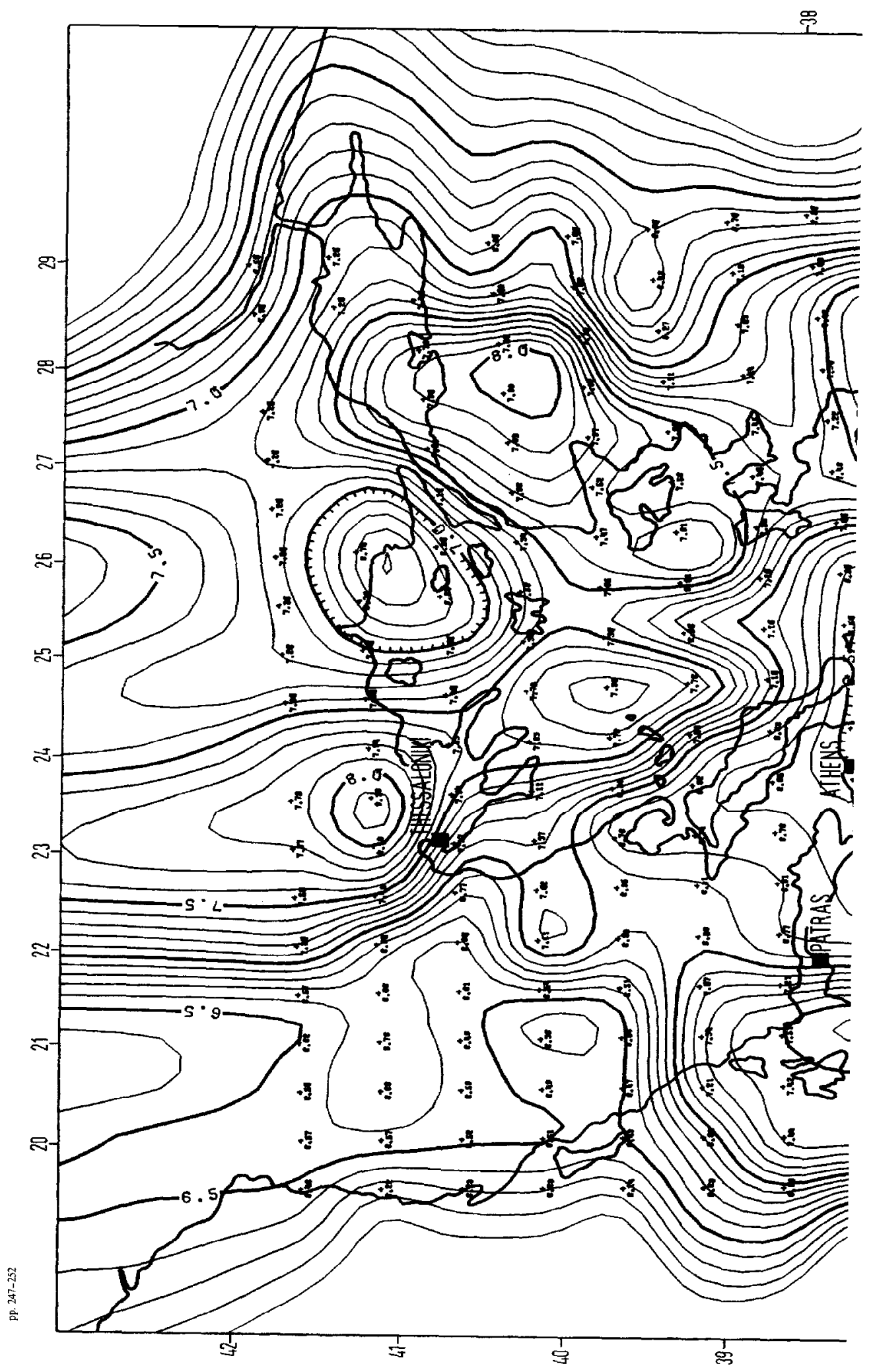




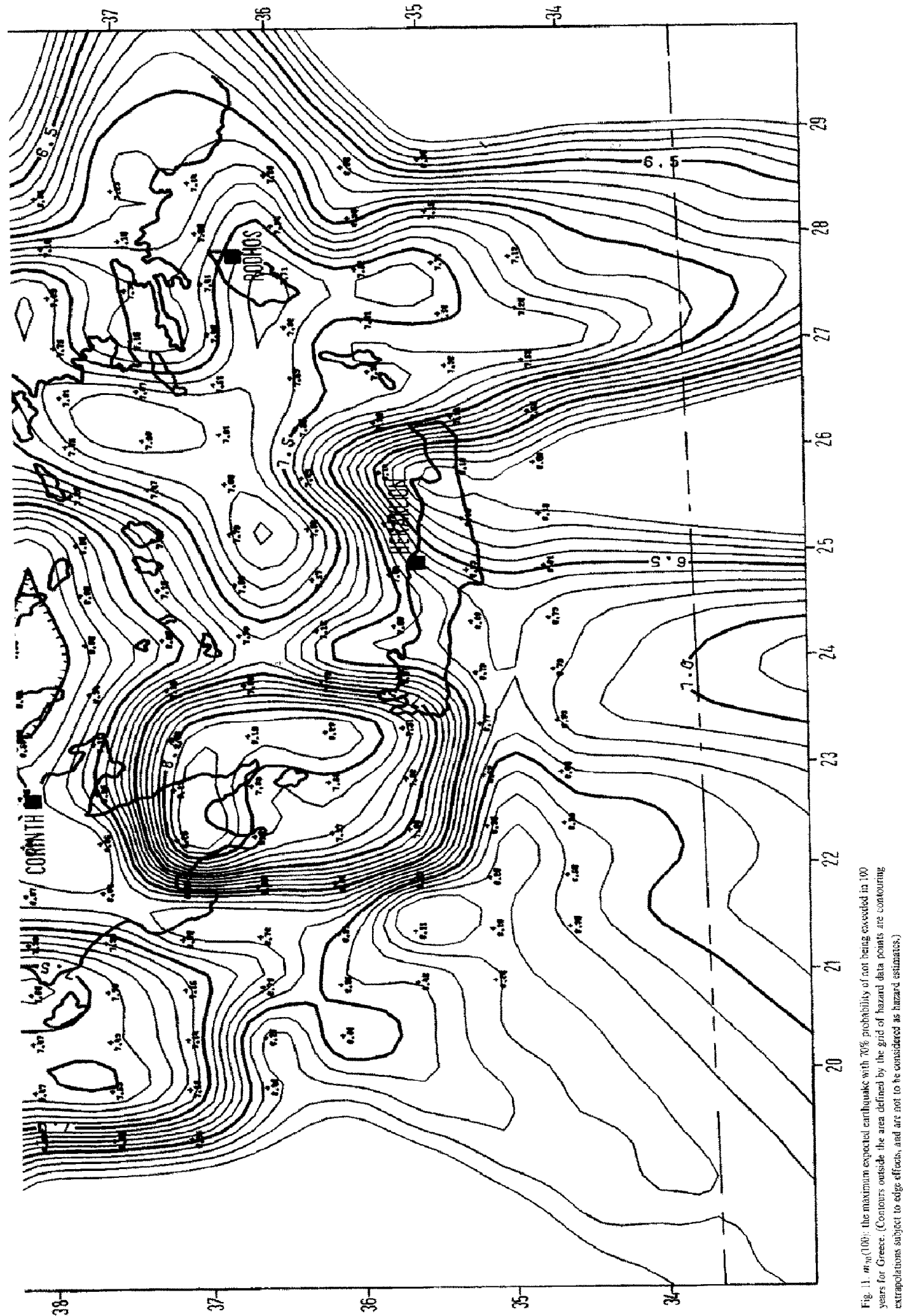


maximum observed earthquake magnitudes during the 78 year sample period were 6.6 (1962 August 28) and 7.0 (1926 August 30) within distances of $100 \mathrm{~km}$ and 150 $\mathrm{km}$ respectively from Athens. The Corinth earthquake of 1981 February 24 is in keeping with this with magnitude $6.6 \mathrm{M}_{\mathrm{s}}$.

The most probable annual maximum magnitudes within the same distances are: $4.5 \pm 0.1$ and $4.8 \pm 0.1$ respectively. The mean annual rates of energy release correspond to earthquakes with magnitudes $5.7 \pm 0.1$ and $6.0 \pm 0.1$. The same quantities from the third type asymptotic distribution analysis have values $5.9 \pm 0.1$ and $6.0 \pm 0.1$ respectively. Table 6 shows remarkably good agreement for both radii between predicted and observed number of exceedances over the whole range of magnitude.

The example of Athens also has special significance in terms of the Gumbel III methodology. Realistic results are obtained even though the number of years with missing extremes is greater than the number of observed extremes.

\section{CONTOUR MAPS OF SPATIALLY DISTRIBUTED MAGNITUDE SEISMIC HAZARD}

Close agreement has been demonstrated between the observed and the predicted extreme magnitude occurrences for Greece as a whole, and for the six selected places, using the Gumbel III extreme value method. Thus, a more detailed evaluation of seismic hazard in terms of maximum magnitudes (and later in terms of ground acceleration) for every part of Greece may be attempted, and contour maps of the distribution of the seismic hazard can be prepared. The region covered is essentially Greece $\left[\mathrm{N}_{33}^{42.5}, \mathrm{E}_{19}^{29}\right]$.

Greece is divided into cells of $0.5^{\circ}$ latitude $\times 0.5^{\circ}$ longitude, and a mesh of grid points with spacing of $0.5^{\circ}$ latitude, $0.5^{\circ}$ longitude, is created for the whole area. All earthquakes occurring within a circle of $1^{\circ}$ radius, with its centre at a particular grid point, are then collected from the MB earthquake catalogue, and their annual maximum observed magnitudes are analysed using the Gumbel III extreme value methodology. For every grid point the parameters and their uncertainties are computed. Each set of parameters corresponds to an area which overlaps the adjacent one by about $3 / 4$. Using eqns. (4), (5), and (6), the annual and 80-year mode, and the maximum magnitude which is expected with $70 \%$ probability of not being exceeded in 50 and 100 years, are then estimated and contoured.

Figures 8-11 show the distribution of seismic hazard in terms of these maximum expected magnitudes. The values in Figs. 10 and 11 combined with Figs. 8 and 9 allow the short-term and long-term hazard in every part of the area to be evaluated and compared.

Comparing these figures obviously shows that the values of maximum annual magnitude are significantly different from the values of the 80 -year mode, but more importantly the two overall pictures also differ in regional detail and contour shape. Figure 9 is not a linear extrapolation of Fig. 8. The reason for this is that every place 
has its own distribution curvature for magnitude occurrence, which shows how quickly the distribution approaches the upper bound. Places in which the distribution of maximum magnitudes has greater curvature (larger value of $\lambda$ ), than other places, show greater difference between the regional contour maps for the annual and 80-year modes. As longer return periods are considered these differences become small, because the expected magnitudes approach the upper bound and so the overall pictures are then ultimately similar. Figures 811 clearly illustrate the development of this important point.

Figure 9 shows the 80-year mode or most expected maximum magnitude during an 80 year period. This period is similar to the time span of the data analysed and is thus most easily compared with the observed seismicity distribution in Fig. 9 of Makropoulos and Burton (MB) (1981). These two figures show very similar general properties, although the means of representation are so different.

The three main aseismic blocks discussed in MB (1981) are clearly defined by contours of $m(80)$ in Fig. 9 as the areas of the lowest seismic hazard in Greece.

Areas with high values of maximum expected magnitudes are also areas where the observed magnitudes have large values. It is expected that during the next 80 years earthquake magnitudes exceeding 7.5 will occur at least once in the area of Greek-Yugoslavia borders, the Chalkidiki peninsula, and the Marmara Sea in northwestern Turkey. These areas have experienced earthquakes with magnitudes 7.8 (1904 April 4), 7.4 (1905 November 8), and 7.4 (1953 March 18) respectively.

Figures 10 and 11, which describe the hazard in terms of maximum magnitude with $70 \%$ probability of not being exceeded in 50 and 100 years, show a similar picture of seismicity. This is because these values correspond to return periods through (7) of about 140 and 280 years, and so they approach their own local upper bound with only small changes in $m$ with increasing return periods. Both these figures clearly show an additional area of high hazard which was poorly defined in Fig. 9. This is the southeastern Peloponnesos and Kithera Island where the largest intermediate depth earthquake in the catalogue occurred with magnitude 8.0 (1903 August 11, $h=120 \mathrm{~km}$ ), although this magnitude is debated and macroseismic evidence would suggest a lower value (Ambraseys, 1981).

The earthquake catalogue for Greece is sufficiently lengthy in relation to the seismicity rate for the hazards estimates to show stability. The MB (1981) catalogue includes earthquakes into 1978 (Comninakis and Papazachos, 1982, include earthquakes into 1980) and so the present study analyses data over the period 1901-1978. It is interesting to note that upto the end of 1983 there were seven further earthquakes with magnitude exceeding $6 M_{\mathrm{s}}$. (Data from the bulletins of the International Seismological Centre detail two Magnesia earthquakes on 1980 July 9 with 6.3 and 6.1 $M$, respectively and three Corinth earthquakes on 1981, February 24 and 25 and March 4, with 6.6, 6.3 and 6.4 $M_{\text {s }}$ respectively. Preliminary determination of epicentre data from the U.S. National Earthquake Infromation Service detail a Cephalonia earthquake on 1983 January 17 with $6.6 M_{\mathrm{s}}(\mathrm{ATH})$ and 
a Lymnos Island earthquake on 1983, August 6, with $6.6 M_{\mathrm{S}}$ (ATH). All of these post-1978 earthquakes occurred in areas of high seismicity, where similar or greater magnitude earthquakes had occurred several times previously, and no statistically significant perturbation arises in the hazard maps as presented here- these occurrences are compatible with the expectation range of magnitudes in these areas during the 5-year period following 1978.

The corrollary to much of the foregoing is that there is a $70 \%$ probability in the next 100 years that the maximum earthquake magnitude will not exceed 8.0 in any of these high hazard areas, and consequently in the whole area of Greece.

\section{CONCLUSIONS}

Seismic hazard has been assessed in terms of expected modal magnitudes using both the method of strain energy release and also the extreme value asymptotic distribution Gumbel III. The results obtained show that where the strain energy release graphs include at least one well defined cycle of energy release, the parameters $(\omega, u, \lambda)$ of Gumbel III have small uncertainties. Inspection of the figures and the corresponding values of reduced chi-square show that the observed magnitude extremes are well fitted by Gumbel III. An empirical comparison of the predicted number of exceedances for different magnitude levels during the sample period with those observed shows close agreement.

Gumbel III adequately reveals the seismic picture of a region and has been applied to Greece as a whole, and to six specific major cities. An upper bound magnitude $\omega=8.73 \pm 0.65$ is obtained, whereas the strain energy release maximum conceivable magnitude is $M_{3}=8.16 \pm 0.43$ for Greece as a whole. There are conceptional differences between $\omega$ and $M_{3}$ in that $\omega$ theoretically corresponds to an infinite return period, whereas $M_{3}$ requires a "waiting time", which for Greece as a whole is 33 years. A magnitude limit in excess of 8.0 is compatible with the seismic history of Greece. An earthquake with magnitude exceeding 5.5 is expected as an annual extreme almost every year. A magnitude exceeding 7.5 is expected every 22 years whereas the exceedance of magnitude 8.0 is extrapolated to about a 200-year return period. Values of $\omega$ are often accompanied by large uncertainties, but for Athens the upper bound magnitude is $\omega=6.8 \pm 0.4$ within an area of $100 \mathrm{~km}$ radius from the city; the modal annual maximum magnitude is $4.51 \pm 0.08$.

The same detailed extreme value evaluation applied to all Greece for cells of $1^{\circ}$ radial extent on a grid spaced at $0.5^{\circ}$ intervals of latitude and longitude produces spatial seismic hazard maps. Parameters representative of different aspects of the seismic hazard are chosen as $m(1), m(80), m_{70}(50)$ and $m_{70}(100)$. A feature common to all these maps is the existence of three well defined aseismic blocks. These are: (1) the Attikocycladic block, (2) the Ptolemais basin block, and (3) the block formed by the northeastern part of Greece. These aseismic blocks of low seismic hazard correlate with the tectonics and indicate that the region cannot be 
modelled by a simple tectonic plate (Makropoulos and Burton, 1984). Also well defined are areas of high seismic hazard which correlate with the tectonically most active areas, and these are: (1) along the Hellenic arc: Greek-Albania-Yugoslavia borders, Leukas and Cephalonia Islands in the Ionian Sea, and the southeastern end of the arc around Rhodes Island, (2) the western end of the Northern Anatolian fault, in the Marmara Sea and Dardenelles area, and (3) the northern Aegean Sea: Chalkidiki peninsula and Sporades Islands.

These maps representing spatial variations of seismic hazard are not simply linear extrapolations of one another. The map of the 80-year mode $m(80)$ showing long term hazard has differences in regional detail and contour shape when compared with the annual mode $m(1)$ map of short term hazard. This is because each place has its own seismicity and distribution curvature specifying how quickly the upper bound magnitude is approached. Saturation of the hazard towards upper bound magnitudes becomes incipiently apparent in the maps of $m_{70}(50)$ and $m_{70}(100)$ which correspond to extrapolated and lengthening average return periods of about 140 and 280 years respectively.

\section{ACKNOWLEDGEMENTS}

K.C.M. is grateful to Professor J. Drakopoulos for leave of absence from the University of Athens. The work of P.W.B. was supported by the Natural Environment Research Council and is published with the approval of the Director of the British Geological Survey (NERC).

\section{REFERENCES}

Algermissen, S.T., Perkins, D.H., Isherwood, W., Gordon, D., Reagot, G. and Howard, C., 1976. Seismic risk evaluation of the Balkan region. Proc. of the Seminar on Seismic Zoning Maps, UNESCO. Skopje, 1975, October 27-November 4, Vol. 2, pp. 173-240.

Alsan, E., Tezuçan, L. and Båth, M., 1975. An earthquake catalogue for Turkey for the interval 1913-1970. Common Report No. 75 of Kandilli Obs., Turkey and Seismol. Inst. Uppsala, Sweden.

Ambraseys, N.N., 1981. On the long term seismicity of the Hellenic Arc. Boll. Geofis. Teor. Appl., 23 : 355-359.

Băth, M., 1958. The energies of seismic body waves and surface waves. In: H. Benioff, M. Ewing, B.F. Howell Jr. and F. Press (Editors), Contributions in Geophysics. Pergamon, London, Vol. 1. pp. 1-16.

Båth, M., 1983. Earthquake frequency and energy in Greece. Tectonophysics, 95: 233-252.

Benioff, H., 1951. Global strain accumulation and release as revealed by great earthquakes, Bull. Seismol. Soc. Am., 62: 331-338.

Burton, P.W., 1978. The application of extreme value statistics to seismic hazard assessment in the European area. Proc. Symp. Anal. Seismicity and on Seismic Risk, Liblice, 1977, October 17-22. Academia, Prague, pp. 323-334.

Burton, P.W., 1979. Seismic risk in Southern Europe through to India using Gumbel's third distribution of extreme values. Geophys. J.R. Astron. Soc., 59: 249-280. 
Burton, P.W. and Makropoulos, K.C., 1983. Seismic risk of circum-Pacific earthquakes: II Extreme values using Gumbel's third distribution and the relationship with strain energy release. Inst. Geol. Sci., Glob. Seismol. Unit Rep., No. 201.

Burton, P.W., Main, I.G. and Long, R.E., 1983. Perceptible earthquakes in the Central and Eastern United States (Examined using Gumbel's third distribution of extreme values). Bull. Seismol. Soc. Am., 73: 497-518.

Comninakis, P.E., 1975. A contribution to the investigation of the seismicity of the area of Greece. PhD. Thesis, Athens University, $110 \mathrm{pp}$.

Comninakis, P.E. and Papazachos, B.C., 1978. A catalogue of earthquakes in the Mediterranean and the surrounding area for the period 1901-1975. Thessaloniki Univ., Geophys. Lab., Publ. No. 5: 96 pp.

Comninakis, P.E. and Papazachos, B.C., 1982. A catalogue of earthquakes in Greece and the surrounding area for the period 1901-1980. Thessaloniki Univ., Geophys. Lab., Publ. No. 5: 146 pp.

Douglas, D., 1976. Joint epicentre determination. Nature, 215: 47-48.

Douglas, A.. Young, J.B. and Lilwall, R.C., 1974. Computer programs for epicentre determination. AWRE Rep., No. 0 28/74, HMSO.

Duda, S.J., 1965. Secular seismic energy release in the circum-Pacific Belt. Tectonophysics, 2: 409-452.

Galanopoulos, A.G., 1960. A catalogue of shocks with $I_{0} \geqslant \mathrm{VI}$ or $M \geqslant 5$ for the years 1801-1958. Seismological Laboratory, Athens University, Athens, $119 \mathrm{pp}$.

Galanopoulos, A.G., 1961. A catalogue of shocks with $I_{0} \geqslant$ VII for the years prior to 1800 . Seismological Laboratory, Athens University, Athens, $18 \mathrm{pp}$.

Galanopoulos, A.G., 1963. On mapping of seismic activity in Greece. Ann. Geofis., 16: 37-100.

Galanopoulos, A.G., 1968. On quantitative determination of earthquake risk. Ann. Geofis., 21: 193-206.

Galanopoulos, A.G., 1972. Annual and maximum possible strain accumulation in the major area of Greece. Ann. Géol. Pays Hell., 24: 467-480.

Gumbel, E.J., 1966. Statistics of Extremes. Columbia University Press, New York, 375 pp.

Gutenberg, B. and Kichter, C.F., 1944. Frequency of earthquakes in California. Bull. Seismol. Soc. Am., 34: $185-188$.

Lommitz, C., 1974. Global Tectonics and Earthquake Risk. Elsevier, Amsterdam, 320 pp.

Makris, J., 1976. A dynamic model of the Hellenic arc deduced from Geophysical data. Tectonophysics, 36: $339-346$.

Makris, J., 1978. The crust and upper mantle of the Aegean region from deep seismic soundings. Tectonophysics, 46: 269-284.

Makropoulos, K.C. and Burton, P.W., 1981. A catalogue of seismicity in Greece and adjacent areas. Geophys. J.R. Astron. Soc., 65: 741-762.

Makropoulos, K.C. and Burton, P.W., 1983. Seismic risk of circum-Pacific earthquakes. I. Strain energy release. Pure Appl. Geophys., 121(2): 247-267.

Makropoulos, K.C. and Burton, P.W., 1984. Greek tectonics and seismicity. Tectonophysics, 106: 275-304.

McKenzie, D., 1978. Active tectonics of the Alpine-Himalayan belt: the Aegean Sea and surrounding regions. Geophys. J.R. Astron. Soc., 55: 217-254.

Papazachos, B.C., 1976a. Evidence of crustal shortening in the northern Aegean region. Boll. Geofis. Teor. Appl., 13: 66-71.

Papazachos. B.C., 1976b. Seismotectonics of the northern Aegean area. Tectonophysics, 33: 199-209.

Richter, C.F., 1958. Elementary Seismology. Freeman, San Francisco, Calif., 766 pp.

Shebalin, N.V., Karnik, V. and Hadzievski, D. (Editors), 1974. Balkan Region--Catalogue of Earthquakes. I INFSCO Project Office, Skopje.

Yegulalp, T.M. and Kuo, J.T., 1966. Application of extremal statistics to the maximum magnitude earthquakes (Abstr.). Eos, Trans. Am. Geophys. Union, 47: 163.

Yegulalp, T.M. and Kupo, J.T., 1974. Statistical prediction of the occurrence of maximum magnitude earthquakes. Bull. Seismol. Soc. Am., 64: 393-414. 